\title{
AKTYWNOŚĆ POLITYCZNA SZLACHTY PODLASKIEJ PODCZAS PIERWSZEGO BEZKRÓLEWIA*
}

Abstrakt: Szlachta województwa podlaskiego w czasie pierwszego bezkrólewia (1572-1574) odbyła szereg zjazdów partykularnych. Najważniejszym z nich był zakończony zawiązaniem konfederacji sejmik wojewódzki w Drohiczynie z 12 marca $1573 \mathrm{r}$.

Słowa kluczowe: życie polityczne, drobna szlachta, Podlasie, bezkrólewie, konfederacja, sądy kapturowe.
Abstract: At the time of the first interregnum (1572-1574) the nobility of the palatinate of Podlasie held a number of conventions, the most important being the palatinate sejmik in Drohiczyn on 12 March 1573, which ended with the establishment of a confederation.

Keywords: Petty nobility, Podlasie, Interregnum, Confederation, Kaptur courts.

Przebieg wypadków w Rzeczypospolitej od śmierci ostatniego Jagiellona do koronacji Henryka Walezjusza cieszy się zainteresowaniem badaczy i doczekał się już kilku opracowań ${ }^{1}$. Przedmiotem badań były zwykle działania czołowych postaci i ważniejszych województw, mniej uwagi poświęcano natomiast staropolskiej „prowincji”. Województwo podlaskie, świeżo „przywrócona” do Korony (1569) kraina drobnej szlachty,

* Za życzliwą pomoc podczas pracy nad niniejszym tekstem chciałbym serdecznie podziękować Tomaszowi Jaszczołtowi oraz Gediminasowi Lesmaitisowi i Michałowi Kopczyńskiemu.

${ }^{1}$ E. Dubas-Urwanowicz, Koronne zjazdy szlacheckie $w$ dwóch pierwszych bezkrólewiach po śmierci Zygmunta Augusta, Białystok 1998; S. Płaza, Próby reform ustrojowych w czasie pierwszego bezkrólewia, 1572-1574, Kraków 1969; idem, Wielkie bezkrólewia, Kraków 1988; S. Gruszecki, Walka o władzę w Rzeczypospolitej Polskiej po wygaśnięciu dynastii Jagiellonów (1572-1573), Warszawa $1969 \mathrm{i}$ in. 
takowego opracowania się nie doczekało. Nie licząc może artykułu Stefana Gruszeckiego ${ }^{2}$, gdzie jednak służyło raczej za tło niż podmiot badań. Przyczyn takiego stanu rzeczy jest co najmniej kilka, z których za podstawową można uznać brak źródeł ${ }^{3}$. Celem niniejszego szkicu jest więc uzupełnienie naszej wiedzy o wydarzeniach lat 1572-1574 na Podlasiu, przede wszystkim w ziemi bielskiej, dzięki poszerzeniu bazy źródłowej o podlaskie akta sądowe z zasobu Narodowego Archiwum Historycznego Białorusi w Mińsku.

W jednej z ksiąg grodzkich brańskich przechowywanych tamże zachowała się oblata konfederacji województwa podlaskiego zawartej w Drohiczynie 12 marca 1573 r. ${ }^{4}$ Dokumentu, który - o ile mi wiadomo - nie był znany poprzednio polskiej nauce ${ }^{5}$. W zasobie mińskiego archiwum znajduje się zresztą lwia część ksiąg sądowych podlaskich ${ }^{6}$. Jednakże dostęp do tych źródeł jest dla polskich badaczy wciąż dość utrudniony, często zachowały się one w nie najlepszym stanie, niekompletnie, ich składki zaś są przemieszane chronologicznie ${ }^{7}$.

Śmierć Zygmunta Augusta została zwięźle odnotowana w brańskiej księdze grodzkiej ${ }^{8}$. Z ważniejszych postaci związanych z Podlasiem obecni byli przy królu Jan Dulski, kasztelan chełmiński oraz m.in. starosta brański i suraski, kasztelan kamieniecki Hieronim Sieniawski, pan na Waniewie, oraz marszałek nadworny litewski Mikołaj Krzysztof Radziwiłł „Sierotka", posesor znacznych dóbr podlaskich, głównie w ziemi drohickiej. Ten ostatni reprezentował jednak możnowładztwo litewskie i jego interesy. Już 15 lipca 1572 r. w liście do stryja, wojewody wileńskiego Mikołaja Radziwiłła „Rudego”, wspominał o planach rewindykacji Podlasia na rzecz Litwy ${ }^{9}$. Podkomorzy mielnicki Kasper Irzykowicz, piszący trzy dni później z Knyszyna o panującej tam zgodzie, raczej ich nie znał. W przeddzień

2 S. Gruszecki, Podlaski fragment walki o władzę po śmierci Zygmunta Augusta, „Rocznik Białostocki" 10, 1970, s. 35-52.

${ }^{3}$ Idem, Walka o władze, s. 27.

${ }^{4}$ Konfederacja woj. podlaskiego, Drohiczyn, 12 III 1573 - Nacional'nyj istoričeskij arhiv' Belarusi [dalej: NIAB], fond 1708, 202, k. 480-485v.

${ }^{5}$ Zob. E. Dubas-Urwanowicz, op. cit., s. 50-57.

${ }^{6}$ M. Kulecki, Pobyt służbowy w Mińsku, „Archeion” 43, 1994, s. 374.

7 Stosunkowo najlepiej dostępne są materiały z terenu z. bielskiej: trzy księgi grodzkie brańskie relacji - z lat 1572 (f. 1744, 5 - błędnie oznaczona jako ziemska), 1573-1574 (f. 1708, 202 - obie z Mińska) oraz 1574 (AGAD, zesp. 87, 6).

${ }^{8}$ NIAB, f. 1744, 5, k. 90v; ANK, Zbiór Zygmunta Glogera [dalej: ZZG] 15, s. 62.

${ }^{9}$ R. Heidenstein, Dzieje Polski od śmierci Zygmunta Augusta do roku 1594. Ksiag XII, tłum. M. Gliszczyński, oprac. W. Spasowicz, t. 1, Petersburg 1857, s. 19; „Kronika za Zygmunta Augusta w Knyszynie zmarłego roku 1572", BR 196, s. 20; H. Lulewicz, Gniewów o unię ciag dalszy. Stosunki polsko-litewskie w latach 1569-1588, Warszawa 2002, s. 80. 
śmierci królewskiej wyjechał stamtąd natomiast starosta tykociński Łukasz Górnicki. Możliwe, że w ostatnich dniach towarzyszył Zygmuntowi Augustowi wojewoda podlaski, starosta drohicki i bielski Mikołaj Kiszka (lub ewentualnie ktoś z jego otoczenia). Trudno powiedzieć, czy obecność podkomorzego mielnickiego, zapewne żywo zainteresowanego zapłatą dworskiego jurgieltu, może świadczyć o zjeżdżaniu się do Knyszyna w lipcu 1572 r. także innych przedstawicieli lokalnej elity szlacheckiej ${ }^{10}$.

Już zaraz po zgonie monarchy obecny przy jego trumnie podkanclerzy koronny i biskup krakowski Franciszek Krasiński wyszedł z inicjatywą zjazdu senatorskiego w Knyszynie ${ }^{11}$. Również obradujące niezależnie od siebie zgromadzenia - małopolskie w Krakowie (14-24 lipca) i wielkopolskie w Łowiczu (16-23/25 lipca) wyznaczyły Knyszyn jako miejsce dalszych rozstrzygnięć. Różniły się jednak daty i charakter projektowanego zjazdu - Małopolanie chcieli zorganizować tu w pierwszej połowie sierpnia ogólną naradę senatorów polskich i litewskich, Wielkopolanie zaś opowiadali się za przeprowadzeniem tutaj na początku września elekcji nowego władcy ${ }^{12}$. Ostatecznie odbył się w Knyszynie w dniach 24-31 sierpnia 1572 r. zjazd senatorski inspirowany przez przywódcę Małopolan marszałka wielkiego koronnego Jana Firleja, z udziałem kilkuosobowej delegacji z Litwy. Wyznaczono tam czas i miejsce elekcji na 13 października pomiędzy Lublinem a Bystrzycą, jednak ostatecznie nie zostało to zrealizowane wobec oporu w innych częściach Rzeczypospolitej. Nie mniejsze kontrowersje wzbudził też drugi punkt uchwały, w którym zapisano na wniosek wysłanników Litwy żądanie zwrotu ziem przyłączonych do Korony w 1569 r. $^{13}$

Chociaż na zjeździe obecni byli J. Dulski i M. Kiszka, na „postanowieniu" knyszyńskim widnieje tylko podpis tego pierwszego ${ }^{14}$. Wojewoda podlaski nie sygnował uchwały zapewne z powodu zawarcia w niej żądań litewskich. Był bowiem zwolennikiem unii, o czym zdawali sobie sprawę sami Litwini ${ }^{15}$. Kiszka był w tej kwestii wyrazicielem woli większości

10 K. Irzykowicz do N.N., Knyszyn, 18 VII 1572, w: A. Kraushar, Nieznana relacya o śmierci Zygmunta Augusta (1572), KH 8, 1894, 3, s. 438-440; por. AGAD, Archiwum Skarbu Koronnego [dalej: ASK] 1, 234, k. 86 (rachunki dworskie); Ł. Górnicki, Dzieje w Koronie Polskiej, oprac. H. Barycz, Wrocław 2003, s. 172-173; Ś. Orzelski, Bezkrólewia ksiagg ośmioro, tłum. i oprac. W. Spasowicz, Petersburg-Mohylew 1856, t. 1, s. 76.

11 E. Dubas-Urwanowicz, op. cit., s. 91.

12 Ibidem, s. 113; R. Heidenstein, op. cit., t. 1, s. 14-15.

13 Postanowienie zjazdu knyszyńskiego 1572, w: E. de Noailles, Henri de Valois et la Pologne en 1572, t. 3, Paris 1867, s. 116-118.

${ }^{14}$ Ibidem, s. 118; E. Dubas-Urwanowicz, op. cit., s. 94-95,

15 J. Kiszka do K. Radziwiłła, Lubcz, 30 X 1572, AGAD, Archiwum Radziwiłłów [dalej: AR] V, 6759, s. 1; Z. Spieralski, Kiszka Mikołaj (zm. 1587), PSB, t. 12, Wrocław 1966-1967, s. 512. 
Podlasian. Znamienne są wspomnienia Reinholda Heidensteina, który odnotował powszechne wówczas mniemanie, że Podlasie, mające większość mieszkańców i przeważającą część szlachty pochodzenia mazowieckiego, było spośród przyłączonych w 1569 r. ziem najbardziej z takiego stanu rzeczy zadowolone ${ }^{16}$. $Z$ kolei Dulski, chociaż podniesiony niedawno do godności senatora, reprezentował w Knyszynie interesy dworzan królewskich ${ }^{17}$. Prawdopodobnie także dzięki jego poparciu, obok prymasowskiego, Fabian Jałbrzyk Wyszyński, protegowany Jakuba Uchańskiego, uzyskał w Knyszynie od senatorów korzystne dla siebie pismo. Jego brat, Andrzej, był bowiem zaufanym sługą starosty brańskiego. Fabian powoływał się również na uniwersał łowicki ${ }^{18}$. Być może i inni miejscowi szlachcice zdecydowali się przybyć do Knyszyna na czas zjazdu. Przeszkodą w tym mógł być jednak strach przed ogarniającą Podlasie epidemią. Pod koniec czerwca z tej przyczyny wojewódzkie sądy wiecowe w Drohiczynie przeniesiono na dzień po św. Marcinie (12 listopada) ${ }^{19}$.

„Morowe powietrze” przywlókł w te strony orszak królewski - ironią losu - uchodząc przed nim z Warszawy. To zaś, jak zanotował w swych wspomnieniach Górnicki, „było barzo wielkie, iż ledwo się przeszedszy pół zimy uspokoiło"20. Zaraza stała się zresztą jedną z przyczyn fiaska sierpniowego zjazdu. Chyba to ona dosięgła biskupa przemyskiego Walentego Herburta, który „rozniemógł się gorączką” i zmarł 29 sierpnia w Bielsku² .

Kolejnym ważnym punktem na mapie bezkrólewia na Podlasiu był Tykocin. W zamku tykocińskim znajdował się skarbiec króla, a także jeden $z$ trzech egzemplarzy jego testamentu, toteż już nazajutrz po śmierci monarszej wysłano tam polsko-litewską deputację z Knyszyna

${ }^{16}$ R. Heidenstein, op. cit., t. 1, s. 4; idem, Rerum Polonicarum ab excessu Sigismundi Augusti Libri XII, Francofurti ad Moenum 1672, s. 2. Miejsce zniekształcone zapewne przez wydawcę - zamiast Masovitici dano Moschovitici, co skonfundowało tłumacza w XIX w.

${ }_{17}$ R. Heidenstein, Dzieje, t. 1, s. 19; Ś. Orzelski, op. cit., t. 1, s. 7; E. Dubas-Urwanowicz, op. cit., s. 103-104.

18 Ojciec obu braci, Marcin, sędzia bielski (1565-1567), posłował z tej ziemi w 1547 r. Stryj Stanisław był chorążym (1551-1563); zob. NIAB, f. 1744, 5, k. 120v-121, 485v; f. 1708, 202, k. 193-193v, 658, 665-665v; ANK, ZZG 15, s. 29, 31, 43; Archiwum Diecezjalne w Siedlcach [dalej: AD Siedlce], D 13, k. 85; VL 1, s. 287; B. Paprocki, Herby rycerstwa polskiego, wyd. K.J. Turowski, Kraków 1858, s. 720; Skarbiec historii polskiej, t. 2, wyd. K. Sienkiewicz, Paryż 1840, s. 19-25; Ś. Orzelski, op. cit., t. 2, s. 280; Urzędnicy, t. 8: Urzędnicy podlascy XIV-XVIII wieku. Spisy, red. E. Dubas-Urwanowicz i in., Kórnik 1994, s. 37, 50, 55, 132.

${ }^{19}$ Uchwała zjazdu wiecowego, Drohiczyn, 26 VI 1572, AGAD, AR II, 86, s. 1-3; o wiecach podlaskich zob. konstytucje sejmu 1569 r. w: VC 2/1, s. 252-253.

${ }^{20}$ Ł. Górnicki, op. cit., s. 238.

${ }^{21}$ Diariusz zjazdu w Knyszynie, BR 196, s. 124. 
do jego opieczętowania ${ }^{22}$. Zarówno Polacy, jak i Litwini obawiali się, że strona przeciwna zechce przejąć twierdzę zbrojnie. Gdy później na mocy uchwały zjazdu knyszyńskiego postanowiono przenieść trumnę z doczesnymi szczątkami króla do Tykocina, doszło do ostrego konfliktu z dowódcą załogi warowni Klemensem (Klimuntem) Bielińskim, a sprawa ciągnęła się przez następne miesiące ${ }^{23}$.

W odpowiedzi na postanowienia knyszyńskie M. Kiszka wspólnie z kasztelanem podlaskim Adamem Kosińskim przeprowadzili zjazd wojewódzki szlachty w Mielniku 15 września 1572 r. Uchwała tego zgromadzenia wspomina także o „urzędnikach i szlachcie ziemi podlaskiej” na nim obecnych, jednak nic ponadto o frekwencji tamże nie wiadomo. Uchwalono, aby na mający się odbyć sejm elekcji stawili się wszyscy urzędnicy i dygnitarze podlascy oraz przynajmniej po jednym przedstawicielu z każdej wsi szlacheckiej. Wyprawiony szlachcic poza tym, że „baczny i godny”, miał być również niedotknięty przez epidemię. Zachęcano ponadto każdego, kto „z dobrej woli” wybrałby się na elekcję, podkreślając niepokojący wydźwięk roszczeń litewskich. Zebrani w Mielniku obstawali przy „świebodach, prawach i iurisdiciej koronnej" oraz przy swej przysiędze danej Koronie. Dlatego jednoznacznie stwierdzono potrzebę „deliberacji” nad tym, jak „ichm. panów litewskich przedsięwzięcie w tej mierze odrazić”. Dokument kończył się wezwaniem do możliwie najszerszego rozpowszechnienia treści uchwały i niezwłocznego wyprawienia się „z zupełną mocą i nauką w takowych rzeczach podaną" ${ }^{24}$. Podobne rozwiązanie dla ubogiej szlachty jeszcze w lipcu proponował woj. sandomierski Piotr Zborowski ${ }^{25}$.

Sprawa elekcji miała się rozstrzygnąć dopiero na konwokacji zwołanej do Warszawy na początek roku 1573 mocą uchwały zjazdu kaskiego (24 X1 XI 1572). Wojewody podlaskiego nie było w Kaskach. Nie był również obecny pośród senatorów małopolskich zebranych wcześniej w Osieku (początek października). Nic nie wiadomo o ówczesnej aktywności Kosińskiego, Dulski zaś prawdopodobnie przebywał wówczas na Podlasiu ${ }^{26}$.

${ }^{22}$ K. Irzykowicz do N.N., Knyszyn, 18 VII 1572, w: A. Kraushar, op. cit., s. 439-440; R. Heidenstein, Dzieje, t. 1, s. 8.

23 Zob. E. Dubas-Urwanowicz, op. cit., s. 102-103, 123, 237, 243; J. Maroszek, Pogranicze Litwy i Korony w planach króla Zygmunta Augusta, Białystok 2000, s. 346-356.

${ }^{24}$ Uchwała zjazdu woj. podlaskiego, Mielnik, 15 IX 1572, BN 3085, k. 16-16v; H. Lulewicz, op. cit., s. 106. Miejsce to wybrano ze względu na zarazę panującą w innych częściach Podlasia.

25 Uniwersał P. Zborowskiego, Stobnica, 11 VII 1572; E. de Noailles, op. cit., t. 3, s. 83; BC 80, s. 732; BK 994, k. 153v; odmienne.

${ }^{26}$ Por. E. Dubas-Urwanowicz, op. cit., s. 136, przyp. 185. W Osieku nie było ani Kiszki, ani kaszt. ciechanowskiego Stanisława Bogackiego, obu „Wielkopolan”, por. E. Kalinowski, 
Urząd grodzki ziemi bielskiej w Brańsku pracował normalnie przez pierwszy miesiąc po śmierci królewskiej. Przewodniczył mu w tym czasie z reguły podstarości Marcin Mieński. Raz tylko, w niedzielę 27 lipca, zjawił się tutejszy starosta Dulski ${ }^{27}$. Działanie grodu przerwało dopiero nasilenie się zarazy. Ostatnie zapisy przyjęto w Brańsku 12 sierpnia 1572 r., z powodu „powietrza” urząd przeniósł się do Suraża, gdzie pierwszy zapis przyjęto 31 sierpnia $^{28} .11$ listopada w Surażu przy Dulskim wpisano do ksiąg uchwały zjazdów z Koła i Kask ${ }^{29}$. Starosta przybył do miasta co najmniej dzień wcześniej ${ }^{30}$. Pisma owe dotarły tu dość szybko, biorąc pod uwagę daty wielkopolskich oblat ${ }^{31}$. Jak zobaczymy, „uniwersał z Koła około kapturu" miał na Podlasiu duże znaczenie podczas bezkrólewia.

Tymczasem poselstwo koronne ze zjazdu kaskiego otrzymało odpowiedź od zebranych w Mścibohowie dygnitarzy litewskich (5-7 XII 1572). Litwini zawarli w niej sformułowane w ostrych słowach żądanie „o podniesienie dekretu przeciw wszemu prawu, a z ubliżeniem wolności na bracią naszą [--] uczynionego" - jak określili przyłączenie do Korony w 1569 r. Podlasia, Wołynia i Ukrainy. W podobnym tonie odpowiedzieli na zarzuty Koroniarzy o wysyłanie tamże listów ze skarbu litewskiego, argumentując, że „tych ziem nigdy ku Polszcze nie odprzysięgali”32. Pogłoski o nastawieniu Litwinów były na tyle niepokojące, że zjazd województwa ruskiego z 14 grudnia 1572 r. wysłał posłów na Wołyń i Podlasie, by rozeznać się w sytuacji ${ }^{33}$. Szlachta ruska wykazała się przy tym swoistą solidarnością z obywatelami wspomnianych województw ${ }^{34}$. Odrzuciła natomiast uniwersał kolski, ostro protestując przeciwko uzurpowaniu sobie władzy nad nią przez Wielkopolan i prymasa ${ }^{35}$.

Podlasianin Wielkopolaninem? Z nieznanych dziejów przynależności terytorialnej Podlasia po 1569 r., PH 106, 2015, z. 3, s. 429, przyp. 51; AGAD, ASK 1, 234, k. 51, 84.

${ }^{27}$ NIAB, f. 1744, 5, k. 113, 209.

28 Ibidem, k. 209.

${ }^{29}$ NIAB, f. 1744, 5, k. 215-220; ANK, ZZG 17, s. 64; zob. też AGAD, ASK 1, 234, k. 28v.

${ }^{30}$ NIAB, f. 1708, 202, k. 137v-138v.

31 ASWP, t. 1: 1575-1632, wyd. W. Dworzaczek, cz. 1: 1575-1616, Poznań 1957, s. 4.

${ }^{32}$ Akta zjazdów stanów Wielkiego Księstwa Litewskiego, t. 1, oprac. H. Lulewicz, Warszawa 2006, s. 47.

${ }^{33}$ E. Dubas-Urwanowicz, op. cit., s. 23-24.

${ }^{34}$ Eadem, Stosunek Korony do unii z Litwa w latach 1562-1574, „Studia Podlaskie” 5, 1995, s. 23.

${ }^{35}$ Instrukcja dana posłom na konwokacya do Warszawy od rycerstwa wszystkich ziem ruskich, w: E. de Noailles, op. cit., t. 3, 235-236. Wielkopolskie redakcje uniwersału kolskiego zbadane przez Włodzimierza Dworzaczka różnią się od podlaskiej właśnie tym, że w miejsce z. chełmińskiej zapisano w oblacie suraskiej z. ruską i chełmską; por. Uchwała zjazdu województw wielkopolskich w Kole 15 października 1572 r., w: ASWP, t. 1, cz. 1, s. 6; Uchwała z Koła około kapturu, NIAB, f. 1744, 5, k. 216v-217. 
O tym, że sejmik przed konwokacją na Podlasiu w ogóle się odbył, możemy wnosić dzięki wiadomościom „z drugiej ręki”. Zgodnie z uchwałą z Kask sejmiki miały się zbierać wszędzie na św. Łucję (13 grudnia). Brak źródeł uniemożliwia odpowiedź na pytanie, czy zebrał się zaplanowany na miesiąc wcześniej (12 listopada) zjazd na wiece do Drohiczyna ${ }^{36}$. Województwo podlaskie wysłało na konwokację „dwu panów posły”. Ta nadzwyczaj niska ich liczba miała związek z trzymaniem się litery uniwersału kaskiego ${ }^{37}$. Z innego źródła wiadomo, że wojewoda wraz ze stanami podlaskimi przyjęli na sejmiku wojewódzkim postanowienia z Koła ${ }^{38}$ i zdecydowali o obsadzie sądów kapturowych ${ }^{39}$. Miało w nich zasiadać prócz starosty czterech przedstawicieli rycerstwa. W ziemi bielskiej wyznaczeni zostali do tego chorąży, wojski, sędzia i podsędek ziemski, czyli kolejno: Jerzy Brzóska, Jan Faraur Łoknicki, Wojciech Wyszkowski i Hipolit Janikowski. W ziemi drohickiej skład był niemal identyczny, lecz zamiast wojskiego sprawy sądzić miał kasztelan podlaski A. Kosiński, a dalej: chorąży (drohicki i mielnicki) Arnolf Hlebowicz, sędzia Jakub Pobikrowski i podsędek Marcin Wąż ${ }^{40}$. Warto zwrócić uwagę w obu przypadkach na swoisty parytet między urzędami stricte sądowymi a „wojennymi”. Przyjęcie uchwał kolskich znalazło odzwierciedlenie w tytułach pozwów. Powoływano się więc na moc prawną konfederacji senatu opublikowanej przez uniwersały, dokładano też klauzulę wspominającą o deputatach. Czasem akcentowano „historyczność” kapturu, co miało służyć legitymizacji precedensowych działan ${ }^{41}$.

${ }^{36}$ Uchwała zjazdu wiecowego, Drohiczyn, 26 VI 1572, AGAD, AR II, 86, s. 2.

37 Konfederacja woj. podlaskiego 1573, NIAB, f. 1708, 202, k. 484v; por. Uniwersał kaski 1572, NIAB, f. 1744, 5, k. 219; BK 994, k. 186. Odnosiło się to bezpośrednio do Inflant, lecz mogło zostać zinterpretowane szerzej. Na Podlasiu wybierano na sejmy po dwóch posłów z każdej ziemi. Inne województwa posłały na konwokację więcej reprezentantów niż zwykle; por. E. Opaliński, Szlachta małopolska a bezkrólewia, KH 105 , 1998, 3, s. 99.

${ }^{38}$ NIAB, f. 1708, 202, k. 476

39 W jednym z pozwów napisano wprost o deputatach wybranych przez szlachtę („per nobilitatem electis”). Ich nazwiska zapewne dopisano później; zob. NIAB, f. 1708, 202, k. 238v; f. 1744, 5, k. 216v. Na Mazowszu część deputatów obrano na sejmiku wojewódzkim, część na powiatowych (BC 2724, s. 355).

40 AGAD, Ks. gr. droh. I, 1, k. 370.

${ }^{41}$ Przykład: „vigore confederationis praesentis per litteras universales consiliariorum Regni Poloniae publicatae" (22 stycznia), NIAB, f. 1708, 202, k. 693; por. Uchwała zjazdu województw wielkopolskich $w$ Kole, s. 6. NIAB, f. 1708, 202, k. 238, 396, 665. Wielkopolanie odnosili się do uchwały z Radomska (1382), Małopolanie - z Nowego Miasta Korczyna (1438). Podobną funkcję spełniała legenda „rokoszu gliniańskiego”; zob. J. Maciszewski, Mechanizmy kształtowania się opinii publicznej w Polsce doby kontrreformacji, w: Wiek XVII - kontrreformacja - barok, red. J. Pelc, Wrocław 1970, s. 66. 
Napór zarazy zelżał z początkiem nowego roku, skoro urząd grodzki powrócił na swoje zwykłe miejsce do Brańska. Już od pierwszych dni do ksiąg zaczęły spływać od woźnych obdukcje ran zadanych sobie przez szlachtę w bójkach podczas moru, gdy urząd nie funkcjonował. Tego typu zeznania wpisywano przez następnych kilka miesięcy ${ }^{42}$. Przyjęto też do ksiąg zapiski dokonywane w czasie zarazy przez M. Mieńskiego. od początku stycznia zaczęły masowo wychodzić też pozwy na przyszłe roki. Sąd kapturowy ziemi bielskiej zebrał się po raz pierwszy 7 stycznia ${ }^{43}$ 1573 r., ze starostą Dulskim na czele. Dlatego ów przybył spóźniony na konwokację do Warszawy. Ze względu na problemy z dostępem do ksiąg, jak i późne dojście wieści o pierwszej sesji, niewiele spraw udało się wówczas załatwić $^{44}$. Także w ziemi drohickiej kaptur zebrał się tegoż dnia ${ }^{45}$. Kolejne roki odbyły się - zgodnie z uniwersałem kolskim - po upływie czterech tygodni, czyli po pierwszej postnej niedzieli (Invocavit - 9 II 1573), a przy tym ok. dwa tygodnie po „odwołaniu” konwokacji ${ }^{46}$. Następne przypadały 9 marca, lecz sędziowie postanowili je suspendować z uwagi na bliski termin sejmiku wojewódzkiego, gdzie miano dyskutować formę sądów ${ }^{47}$.

Warszawski zjazd konwokacyjny zebrał się zgodnie z planem w dzień święta Trzech Króli. Obradując w dniach 6-29 stycznia 1573 r., uchwalił konfederację generalną z zapisami o tolerancji religijnej, podatki, ustalił czas i miejsce elekcji (5 kwietnia, Kamień pod Warszawą) oraz zwołał na 2 marca sejmiki ${ }^{48}$. Litwini wysłali na konwokację tylko 11 przedstawicieli

42 Pierwsze pozwy datowano z Brańska już 1 grudnia 1572 r., z kolei na innym, z 20 grudnia, dopisano „in loco tunc officii residentionis”, co może świadczyć, że faktycznym miejscem wydania był jednak Suraż; zob. NIAB, f. 1708, 202, k. 100, 111, 563563v, 634-635, 639v-640v, 658-658v, 661v, 665-665v i in.

43 Data tej sesji sądu zachowała się tylko szczątkowo (ibidem, k. 665: [feri]a quarta in cr[astino]), a przemieszanie chronologiczne kart w księdze dodatkowo utrudnia interpretację źródła.

${ }^{44}$ Ibidem, k. 671-671v, 683, 684.

${ }^{45}$ AGAD, Ks. gr. droh. I, 1, k. 370. Tutaj data także jest uszkodzona, lecz czytelna.

${ }^{46}$ Jeden z pozwów ze stycznia wzywa strony przed sąd „pro feria secunda post exclamationem convocationis ad electionem novi Regis", tj. 2 lutego (NIAB, f. 1708, 202, k. 237v). Doszło tu chyba do zniekształcenia treści poprzez „korektę” pierwotnego zapisu rodzaju: „,pro secunda feria secunda”. Ogromna większość zachowanych pozwów sugeruje datę 9 lutego (ibidem, k. 236-241v, 243v, 452-452v, 492, 581-581v, 584-584v, 692-694 i in.; por. k. 724-724v). Uderzające jest podobieństwo do uchwały marcowej konfederacji (ibidem, k. 481).

${ }^{47}$ W owym zapisie występuje „pan kasztelan” (zapewne chełmiński - J. Dulski) wraz z deputatami, których nie wymieniono jednak poprzednio w nagłówku z datą; NIAB, f. 1708, 202, k. 585, 597.

${ }^{48}$ E. Dubas-Urwanowicz, Koronne zjazdy, s. 50, 224; Zbiór pamiętników do dziejów polskich, wyd. W.S. de Broel-Plater, t. 3, Warszawa 1858, s. 22-31. 
z senatu (2) i rycerstwa (9). Podczas długiego, trwającego ponad dwa tygodnie zjazdu senatorsko-szlacheckiego w Wilnie (20 XII 1572-5 I 1573) spisano przesłanie, które owi wysłannicy mieli dostarczyć stanom koronnym. Przepisano tam fragmenty na temat Podlasia i innych ziem „zabranych” w 1569 r. z odpowiedzi danej poprzednio posłom Koronia$\mathrm{rzy}^{49}$. Ci zreferowali ją zebranym na konwokacji (15 I 1573) ${ }^{50}$. Oficjalnej odpowiedzi litewskiemu poselstwu udzielono już po zakończeniu obrad (30 stycznia) - senat koronny odrzucił w niej jego żądania ${ }^{51}$. Litwini nie dawali za wygraną i znów poruszyli sprawę restytucji owych ziem w liście wysłanym na sejmiki w Koronie ze zjazdu w Wilnie (21 II 1573) 52. $^{52}$

Przedstawicielem ziemi bielskiej na konwokacji był Sebastian Brzozowski, syn podkomorzego Teofila i poseł na poprzedni sejm (1572), który 19 lutego 1573 r. oblatował w Brańsku akt konfederacji generalnej, choć sam jej nie podpisał. Przy tym zaznaczył, że posłem został „wybrany i postanowiony” („electus et destinatus”) ${ }^{53}$. Wśród podpisanych pod konfederacją warszawską znaleźć można za to podkomorzego drohickiego Melchiora (Malchera) Niecieckiego, raczej katolika niż protestanta ${ }^{54}$. Ten reprezentował zapewne nie tylko ziemię drohicką, ale i mielnicką. Pod aktem konfederacji generalnej złożyli też swoje podpisy senatorowie związani z Podlasiem: J. Dulski i H. Sieniawski. Dulskiego wyznaczono do komisji mającej po raz kolejny zająć się sprawą Tykocina i krnąbrnego rotmistrza zamkowego. Innym jej członkiem został Piotr Wiesiołowski, właściciel Białegostoku, choć jako reprezentant Litwy ${ }^{55}$. O udziale w konwokacji senatorów podlaskich - wojewody i kasztelana - znane mi źródła i literatura przedmiotu milczą ${ }^{56}$.

${ }^{49}$ Akta zjazdów, t. 1, s. 58-65; por. E. Dubas-Urwanowicz, Koronne zjazdy, s. 228.

${ }^{50}$ Zbiór pamiętników do dziejów, t. 3, s. 2.

51 E. Dubas-Urwanowicz, Stosunek Korony, s. 23; H. Lulewicz, op. cit., s. 131-132.

${ }^{52}$ Akta zjazdów, t. 1, s. 67-70; R. Heidenstein, Dzieje, t. 1, s. 58.

${ }^{53}$ W. Budka, Kto podpisał konfederację warszawska 1573 r.?, „Reformacja w Polsce” 1, 1921, nr 4, s. 318-319. Pomimo świetnie zapowiadającej się kariery wybrał niebawem (1579/1580) stan duchowny; Urzędnicy, t. 8, s. 48; Z. Romaniuk, Sebastian Brzozowski (1547-1588), w: Słownik biograficzny białostocko-łomżyński, t. 1, Białystok 2002, s. 18-19. O negatywnym stosunku Brzozowskiego do reformacji świadczą jego słowa na sejmie 1572 r.; zob. Jagiellonki polskie w XVI wieku, wyd. A. Przezdziecki, t. 3, Kraków 1868, s. 363.

${ }^{54}$ M. Nieciecki jeszcze w 1565 r. był kolatorem katolickiego kościoła w Jabłonnej Rospondowej (Lackiej); AD Siedlce, D 12, k. 56v; Włodzimierz Budka (op. cit., s. 316) chyba po prostu skojarzył nazwisko z protestantem Samuelem; zob. L. Chmaj, Bracia polscy. Ludzie, idee, wptywy, Warszawa 1957, s. 41.

${ }_{55}$ H. Lulewicz, op. cit., s. 122, 133; J. Maroszek, op. cit., s. 441, 505.

${ }^{56}$ Zob. np. E. Dubas-Urwanowicz, Koronne zjazdy, s. 228-229. 
Jak wynika z badań Ewy Dubas-Urwanowicz, marcowe zgromadzenia w Koronie zdominowały trzy kwestie: „problem uprawnień zjazdu konwokacyjnego, kwestia poboru i porządek elekcyjny", zapisy o pokoju religijnym dyskutowano zaś tylko na części z nich ${ }^{57}$. Nie zawsze zbierały się one w terminie wyznaczonym na konwokacji (2 marca), lecz niemal wszędzie w pierwszej połowie marca. Wynikało to z chęci poznania przez niektóre województwa i ziemie najpierw zdania sąsiadów, innym razem limitowano obrady z powodu lokalnych sporów. Konfederacja generalna stwierdzała m.in.: „Sprawiedliwości porządek taki w mocy zachowujemy, jaki sobie ktore województwo doma spolnie postanowiło abo jeszcze postanowi zgodnie" 58 . Wprost zachęcano więc do tworzenia regulacji prawnych na czas bezkrólewia wszędzie tam, gdzie ich jeszcze dotąd nie uchwalono. Należy zatem nieco skorygować stwierdzenie E. Dubas-Urwanowicz, że „zjazdy partykularne w tym okresie nie zawiązywały konfederacji”, gdyż takie próby były podejmowane (Podlasie, Prusy Królewskie), choć na różne sposoby i z różnymi skutkami ${ }^{59}$.

Inicjatywa zwołania sejmiku wojewódzkiego w Drohiczynie wyszła od M. Kiszki. Listy wojewody z wezwaniem na 12 marca publikowane były przez woźnych ok. trzy tygodnie przed datą zebrania - przy kościołach parafialnych lub na rynkach miast ${ }^{60}$. Z tego wniosek, że musiały być wydane jeszcze w lutym. Sejmiki partykularne w terminie wyznaczonym przez konwokację (2 marca) na Podlasiu chyba więc w ogóle się nie odbyły ${ }^{61}$. Wiele o motywacji wojewody mówi manifestacja złożona w Brańsku przez sługę Chądzyńskich, szlachcica Jana Gałązkę ${ }^{62}$. Anna i Piotr, żona i bratanek zmarłego dzierżawcy starostwa kleszczelskiego Stanisława Chądzyńskiego ${ }^{63}$, wiedli bowiem o wspomniane dobra spór z Kiszką. Wystarali się nawet o mandat prymasa na swą korzyść (Uniejów, 21 XII 1572), bo zgodnie z uniwersałem kolskim to arcybiskup gnieźnieński miał rozstrzygać konflikty o dobra królewskie ${ }^{64}$.

57 Ibidem, s. 50-57; por. M. Korolko, Spory i polemiki wokót konfederacji warszawskiej w latach 1573-1576, OiRP 17, 1972, s. 72-74.

58 VC 2/1, s. 307; NIAB, f. 1708, 202, k. 569v.

59 E. Dubas-Urwanowicz, Koronne zjazdy, s. 57; Z. Naworski, Sejmik generalny Prus Królewskich 1572-1772. Organizacja i funkcjonowanie na tle systemu zgromadzeń stanowych, Toruń 1992, s. 47, 82, 106, 151.

${ }^{60}$ Konfederacja woj. podlaskiego 1573, NIAB, f. 1708, 202, k. 480-480v.

${ }^{61}$ NIAB, f. 1708, 202, k. 398v.

${ }^{62}$ Ibidem, k. 476-477v. Tego samego dnia oblatowano tam uchwały konfederackie.

${ }^{63}$ Ów tytułował się podkomorzym drohickim równolegle z M. Niecieckim, został jednak pozbawiony urzędu w styczniu 1567 r.; Lietuvos metrika (1566-1572). Viešujų reikalu knyga 8, Kn. Nr. 530, wyd. D. Baronas, L. Jovaiša, Vilnius 1999, s. 50-51.

${ }^{64}$ Stanisław Chądzyński żył jeszcze w sierpniu 1572 r. List prymasa wpisano do 
Według jego oponentów wojewoda celowo zwołał teraz swymi listami „niejaką konwokację do Drohiczyna”, gdzie przyjęta została „niejaka uchwała" ${ }^{65}$, mocno różniąca się od postanowień kolskich. Wypomnieli mu przy tym, że aprobował te ostatnie na poprzednim zjeździe (zapewne w grudniu 1572), teraz zaś im się sprzeniewierzył, jak również zlekceważył pismo prymasa. Co charakterystyczne, po zwróceniu im starostwa, Chądzyńscy podporządkowali się jurysdykcji sądów konfederackich ziemi bielskiej ${ }^{66}$. Rzeczywiście, w konfederacji uchwalonej przez Podlasian próżno by szukać regulacji o spornych dobrach królewskich, czego zapewne dopilnował sam wojewoda, lecz nadal zasadniczo była ona wzorowana na uniwersale kolskim. Na tyle, że w tytułach pozwów pisano nieraz, iż w Drohiczynie dokonano „objaśnienia” uchwał z Koła ${ }^{67}$. Nawet jeśli u podstaw dyskusji nad „nowym sposobem sądów” leżały prywatne animozje elit możnowładczych, analogicznie jak w Płockiem, to przedstawiciele średniej i drobnej szlachty wykorzystali nadarzającą się okazję także do przeforsowania swoich postulatów.

O przebiegu zjazdu wiemy niewiele ponad to, ile zawiera w sobie oblata konfederacji, do której nie dołączono niestety żadnych podpisów. Dokument wspomina ogólnikowo o zebranych dygnitarzach, urzędnikach i ponoć licznej szlachcie oraz o wielu woźnych ze wszystkich ziem podlaskich. Przewodniczyli im senatorowie: wojewoda M. Kiszka oraz kasztelan A. Kosiński. Z treści konfederacji wynika, że przy obradach mogli być obecni przedstawiciele miast podlaskich ${ }^{68}$. Poza tym wymieniono trzech podstarościch grodzkich - prócz Mieńskiego także Macieja Szymanowskiego (Drohiczyn) i Mikołaja Zaleskiego (Mielnik). Ci musieli solennie zapewnić o podaniu daty zjazdu do powszechnej wiadomości, była to bowiem powinność urzędu ${ }^{69}$. Aby umożliwić szlachcie bielskiej wzięcie

ksiąg 2 stycznia 1573 r., a nazajutrz woźny dostarczył go do Kleszczel, NIAB, f. 1708, 202, k. 445-448, 635-635v, 686; f. 1744, 5, k. 119; Ś. Orzelski, op. cit., t. 1, s. 15.

${ }^{65}$ NIAB, f. 1708, 202, k. 476v. Używane tu sformułowania „niejaka”, „niejakie” (quaddam, quoddam) mają odcień negatywny; zob. niżej.

${ }^{66}$ Kleszczele wróciły do Chądzyńskich co najmniej w czerwcu 1573 r.; pod koniec roku poddani starostwa skarżyli się już na wdowę po Stanisławie, Annę Hińczankę; NIAB, f. 1708, 202, k. 85v, 249, 280.

${ }^{67}$ Występowały takie sformułowania, jak „vigore confederationis statuum Regni [Polo]niae et in Drogicin nuper approbatae et illustratae” (data niezachowana); „nuper illustratae” (15 III 1573) czy „nuper elucidatae” (czerwiec 1573); ibidem, k. 242v, 244v, 682. „Elucydacją” uchwały z Radomska nazwali swoją zebrani w Kole, kolskiej zaś Mazowszanie; zob. ASWP, t. 1, cz. 1, s. 5; BC 2724, s. 348.

${ }^{68}$ Konfederacja woj. podlaskiego 1573, NIAB, f. 1708, 202, k. 483; por. Konfederacja woj. podlaskiego, Brańsk, 21 I 1587, NIAB, f. 1706, 11, k. 144v-145.

${ }^{69}$ E. Dubas-Urwanowicz, Koronne zjazdy, s. 50. 
udziału w drohiczyńskim zjeździe, zawieszono roki sądowe w Brańsku $(9 \text { marca })^{70}$. Owe zabiegi okazały się jednak zdaniem wielu niewystarczające, a frekwencja szlachty nieurzędników - rozczarowująca. Stąd zarzuty uczestników zjazdu do podstarościch oraz protestacja - „większej części" - szlachciców nieobecnych na sejmiku, którzy skarżyli się na brak wiadomości o nim ${ }^{71}$. Wydaje się, że prócz tego incydentu sejmik przebiegał bez większych zakłóceń, skoro tego samego dnia spisano uchwały i przyjęto je do ksiąg drohickich, a obecny przy tym podstarości Mieński zdążył powrócić do Brańska (ok. $50 \mathrm{~km}$ ) i tam jeszcze przyjąć pewną protestację do grodu. Wynika z niej, że na początku marca w Warszawie przebywał H. Sieniawski, który porozumiewał się z pisarzem bielskim (rodem z ziemi łęczyckiej) Tomaszem Owsianym ${ }^{72}$. Uniwersały konfederackie znalazły się w Brańsku 16 marca.

$\mathrm{Na}$ wstępie pierwszego $\mathrm{z}$ dwóch dokumentów wskazuje się powody zawiązania konfederacji. Podlasianie akcentowali swoją wolność szlachecką, która z jednej strony „tempore interregni gubernacula Regni przy żadnej osobie cierpieć nie może, a w nierządzie też i w swej wolej szkodliwa jest i niebezpieczna"73. Znając postawę prymasa w sporze wojewody z Chądzyńskimi, można doszukiwać się tutaj przytyku do osoby interreksa. Chociaż sformułowanie jest tak zręczne, że i przeciwnicy Kiszki mogliby się pod nim podpisać. By odsunąć perspektywę anarchii, Podlasianie zgodzili się dobrowolnie przyjąć regulacje prawne, które pozwolą zachować w tym szczególnym momencie porządek. Miały im podlegać tylko występki popełnione po śmierci króla. Zdecydowano, że zarówno w sprawach kryminalnych, jak i cywilnych pokrzywdzonym będzie wolno wypisać wszystkie krzywdy w jednym pozwie. Chciano przez to ulżyć „ubogim ludziom jednego pamiętnego płaceniem”, co nie było zresztą nowym postulatem ${ }^{74}$. Wymieniono dalej bardzo precyzyjnie poszczególne kategorie aktów przemocy. Surowo karane miały być wszelkie zranienia i zabójstwa - dokonane osobiście lub przez

70 NIAB, f. 1708, 202, k. 597.

${ }^{71}$ Ibidem, k. 398-399. Por. sytuację w woj. płockim z lat 1572-1573 (Z. Lasocki, Szkice z życia szlachty zawkrzeńskiej w XV i XVI wieku, „Miesięcznik Heraldyczny” 11, 1932, nr 3, s. 53-55).

72 NIAB, f. 1708, 202, k. 471-471v.

73 Oryginalny tytul: Constitutio seu Confederatio Militiae terris et Nobilitatis Pallatinatus Podlachiae sub interregno laudata, NIAB, f. 1708, 202, k. 480; por. Fragment diariusza sejmu warszawskiego z roku 1572, wyd. S. Bodniak, „Pamiętnik Biblioteki Kórnickiej”, z. 4, 1947, s. $159-163$.

${ }^{74}$ Konfederacja woj. podlaskiego 1573, NIAB, f. 1708, 202, k. 481; por. suplika z 1565/6 r.: Dokumenty Moskovskogo arhiva Ministerstva ûsticii, t. 1, wyd. M.V. Dovnar-Zapol'skij, Moskva 1897, s. 188-189. 
sługi oraz pomocnictwo ${ }^{75}$. Podlegały karze w równym stopniu tego rodzaju występki przeprowadzone „odpowiednie”, czyli po uprzedniej zapowiedzi, „odpowiedzi”76. Wśród innych ciężkich przestępstw wymieniano m.in. różnego rodzaju łupiestwa, napady na drogach, gwałty (nasilstwa, rapty i stupra), które miały wiązać się z podobnymi, sroższymi karami. Nieodwracalne uszkodzenie tekstu nie pozwala jednak zapoznać się $\mathrm{w}$ pełni z treścią tej części dokumentu ${ }^{77}$. Wiadomo, że „o insze krzywdy niedotkliwe”, takie jak wypędzenie (wybicie) z jakiejkolwiek posesji w dobrach duchownych lub świeckich, miano dochodzić sprawiedliwości po dawnemu. Odwoływano się do prawa koronnego i „przywileju podlaskiego” z 1569 r., akcentując swój jednoznaczny stosunek do postanowień unii. Gołym okiem widoczne jest wzorowanie się na uniwersale kolskim ${ }^{78}$.

Dokument konfederacji ustalił ponownie obsadę sądów kapturowych, osobnych dla każdej z ziem województwa, które miały się składać z urzędników ziemskich i przydanych im deputatów ze szlachty ${ }^{79}$. Roki w Drohiczynie, Mielniku i Brańsku ustanowiono najpierw „po odwołaniu sejmu elektiej we dwie niedzieli”, następnie co każde cztery tygodnie. W ziemi drohickiej sądzić mieli: starosta drohicki M. Kiszka (zarazem wojewoda), podkomorzy M. Nieciecki, chorąży A. Hlebowicz, sędzia ziemski J. Pobikrowski, podsędek M. Wąż, pisarz grodzki Franciszek Gałecki oraz deputaci Sebastian Suchodolski (referendarz podlaski) i Stanisław Krupicki. W mielnickiej - miejscowi: sędzia ziemski Piotr Patkowski, podsędek Wojciech Dziatkowski, pisarz ziemski Wojciech Korzeniowski oraz deputaci Krzysztof Orzeszko, Wojciech Biernacki (sędzia grodzki mielnicki) i Bartosz Wojno. Znaczący jest brak starosty mielnickiego Macieja Sawickiego oraz podkomorzego K. Irzykowicza. O ile zrozumiała mogła być nieufność względem Sawickiego, silnie związanego z Radziwiłłami, to wydaje się, że Irzykowicz, mimo dwuznacznej postawy w 1569 r.,

${ }^{75}$ Miejsce w tekście mocno uszkodzone. Groził tu pozew o gardło i inne kary, zależnie od ciężaru przewiny; zob. konfederacje woj. podlaskiego 1573 i 1587, NIAB, f. 1708, 202, k. 480v-481; f. 1706, 11, k. 142v-143.

${ }^{76}$ Zob. N. Starczenko, Zapowiedź zemsty na Wołyniu w 2. połowie XVI - na początku XVII wieku, „Barok. Historia, literatura, sztuka” 18, 2011, 1, s. 283-312; W. Łoziński, Prawem i lewem. Obyczaje na Czerwonej Rusi w pierwszej połowie XVII wieku, oprac. J. Tazbir, Warszawa 2005, s. 62-68.

77 Ten fragment ma podobne brzmienie w Konfederacji woj. podlaskiego 1587, NIAB, f. 1706, 11, k. 142v-143.

78 Zob. Uniwersał kolski 1572, NIAB, f. 1744, 5, k. 216-218v; ASWP, t. 1, cz. 1, s. 4-8 (zwłaszcza k. 216v i - odpowiednio - s. 5-6).

${ }^{79}$ Konfederacja woj. podlaskiego 1573, NIAB, f. 1708, 202, k. 481, 484v; Urzędnicy, t. 8 , s. $37,43,48,50,55,61,67,79,82,86,91,109,116,119,150$. 
nie chciałby już chyba zerwania $\mathrm{z}$ Koroną ${ }^{80}$. W ziemi bielskiej wreszcie obsadę sądu stanowili: starosta brański J. Dulski, podkomorzy bielski Teofil Brzozowski, chorąży J. Brzóska, sędzia ziemski W. Wyszkowski, podsędek H. Janikowski, pisarz ziemski T. Owsiany oraz deputaci ze szlachty Paweł Gołasz Mościcki (stolnik podlaski) i J. Łoknicki (wojski bielski). Wśród sędziów kapturowych bielskich i drohickich (chyba więc także i mielnickich) znaleźli się $\mathrm{w}$ większości ci mianowani poprzednio. Kilku z nich posłowało na sejmy w ostatnich latach (1569-1572) ${ }^{81}$.

W dalszej części tekstu konfederacji postanowiono, znów wzorując się na dokumencie z Koła, aby w sprawach trudniejszych do rozstrzygnięcia stosować śledztwo (scrutinium) na miejscu przestępstwa, które miało przeprowadzać trzech deputatów. Jak się okazało, w praktyce posyłano na scrutinia zwykle tylko dwóch deputatów, a co najmniej raz śledztwo przeprowadzone zostało jednoosobowo. Nie przewidywano apelacji od wyroków kapturu, z wyjątkiem spraw kryminalnych i „o stracenie wszytkiej majętności”, gdzie dopuszczono możliwość apelowania na „sejm bliski” ${ }^{82}$. Dalej zastrzegano, że apelacje nie przysługują również w sprawach o długi czy inne podobne zapisy majątkowe. Uznano więc faktycznie ważność zapisów czynionych w czasie bezkrólewia, a także aktów wydawanych podczas grasowania zarazy, byle tylko „znacznie [tu: właściwie, za wiedzą stron] uczynionych"\$3.

Wiele uwagi poświęcono problemowi zbiegostwa chłopów. Szlachta skarżyła się, że po przejściu epidemii szczególnie wymarłe na jej skutek

80 Zob. Urzędnicy, t. 8, s. 114, 123; I. Kaniewska, Sawicki Maciej (Matys) h. Lubicz (zm. 1581), PSB, t. 35, Wrocław 1994, s. 334-336. We wrześniu 1572 r. zamiast na podlaskim zjeździe w Mielniku (gdzie rezydował jako starosta) Sawicki był wśród Litwinów w Wilnie; Polskie przypadki Henryka Wolfa z Zurychu. Dziennik podróży z lat 1570-1578, oprac. L. Kieniewicz, tłum. R. Sochoń, M. Szymański, Warszawa 1996, s. 59; J. Maroszek, op. cit., s. 456; Dnevnik Lûblinskogo sejma 1569 goda. Soedinenie Velikogo Knâžestva Litovskogo s Korolestvom Pol'skim, wyd. M.O. Koâlovič, S.-Peterburg 1869, s. 169-171; K. Irzykowicz do N.N., Knyszyn, 18 VII 1572, w: A. Kraushar, op. cit., s. 439-440 (akcentowanie zgody); Akta unii Polski z Litwa, 1385-1791, wyd. S. Kutrzeba, W. Semkowicz, Kraków 1932, s. 341, 355. Być może znaczenie miało też i to, że K. Irzykowicz i M. Sawicki byli kalwinami.

${ }^{81}$ Zob. NIAB, f. 1708, 202, k. 45v, 398, 406, 481, 665; ANK, ZZG 15, s. 63-64. Posłowali: W. Biernacki (1572), T. Brzozowski (1569), P. Mościcki (1570), S. Suchodolski (1570, 1572), W. Wyszkowski (1570); Posłowie ziemscy koronni 1493-1600, red. I. Kaniewska, Warszawa 2013, s. 190-191, 199, 206-207; L. Kolankowski, Posłowie sejmów Zygmunta Augusta, „Reformacja w Polsce” 5, 1928, nr 17/18, s. 134, 136, 138. Nazwisko Mościckiego zostało przekręcone w źródle (Moscziczki - Marsziczki; por. AGAD, ASK 1, 227, k. 16v i 38v). Nieciecki był posłem na konwokację.

82 Por. Uniwersał kolski 1572, ASWP, t. 1, cz. 1, s. 6-7. Zob. NIAB, f. 1708, 202, k. 7172, 131, 396av, 398, 399, 658, i in.

${ }^{83}$ Por. VC 2/1, s. 307 (pkt 6 i 7). 
miasta i dobra królewskie „podkradały” poddanych z dóbr dziedzicznych. Postanowiono obostrzyć prawo przeciwko wszystkim tym, którzy przyjmowali zbiegłych chłopów. W razie niewydania zbiega i udowodnienia winy, każdy przechowujący cudzego poddanego miał zapłacić 14 grzywien oraz wydać go wraz z całym dobytkiem. Aby uniknąć powodu do zatargów, dozwolono szlachcie pozywać przed kaptur o nieuczynienie sprawiedliwości z poddanym albo z mieszczaninem jego pana (także starostę czy dzierżawcę dóbr królewskich) lub urząd miejski ${ }^{84}$.

Szczególnie ujęto się za szlachtą tykocińską, która wbrew zaprzysiężonemu przez nią przywilejowi przywrócenia Podlasia do Korony była nadal zmuszana do rozmaitych posług czy opłat. Nie padło tu co prawda jego imię, lecz z pewnością chodziło konkretnie o tamtejszego starostę Górnickiego. W kilkanaście lat później tekst konfederacji po śmierci Stefana Batorego (1587) otwarcie już go za to piętnował, grożąc wręcz zbrojną rozprawą. Nie był to nowy postulat, gdyż Podlasianie zanosili podobne prośby w sprawie szlachty „niewolnej” na sejmach 1568 i $1569 \mathrm{r}^{85}$ W dalszej części tekstu konfederacji z 1573 r. starano się też o pokojowe rozwiązywanie sporów granicznych pomiędzy dobrami szlacheckimi i królewskimi. Jeszcze raz powrócono do łamania praw koronnych przez starostów i dzierżawców, wspominając o wyciąganiu od szlachty, jej poddanych oraz miast różnych dawnych ceł, poborów i myt. Szczególnie miasta skarżyły się na wykraczanie przeciw przywilejowi z 1569 r., akcentując uniwersały koronne oraz „przysięgi ich koronne uczynione”.

Konfederacja zajęła się także problemem bezpieczeństwa w sądach. Np. w Brańsku ciasnota dworu sądowego oraz krewkość i awanturniczość miejscowych szlachciców doprowadzały nieraz do sytuacji uwłaczających powadze urzędu ${ }^{87}$. Zabroniono więc stawać przed sądem w liczniejszym orszaku „niźli samotrzeć z prokuratorem” (tu: prawnikiem, obrońcą) lub z rusznicą ${ }^{88}$. Każdy, kto nie zastosowałby się do tych przepisów, miał

${ }^{84}$ Konfederacja woj. podlaskiego 1573, NIAB, f. 1708, 202, k. 482.

85 Ibidem, k. 482v; Konfederacja woj. podlaskiego 1587, ibidem, f. 1706, 11, k. 144v; ANK, ZZG 17, s. 450-451; 18, s. 155; Z. Dunin-Kozicki, Nieznane pismo Łukasza Górnickiego o szlachcie wolnej i niewolnej, „Miesięcznik Heraldyczny” 4, 1911, nr 1/2, s. 4-6, nr 3/4, s. 40 43; I.T. Baranowski, Sprawa szlachty poddańczej w starostwie Tykocińskim: z powodu artykułu ks. Zygmunta Dunin-Kozickiego, PH 13, 1911,z. 2, s. 248-254; por. Akta unii, s. 196-207, 236-264.

${ }^{86}$ Konfederacja woj. podlaskiego 1573, NIAB, f. 1708, 202, k. 483; por. postawę miast podlaskich w 1569 r., Akta uni, s. 219-220, 227-228; Dnevnik, s. 233; Źródłopisma do dziejów unii Korony Polskiej i W.X. Litewskiego, cz. 3: Diariusz Lubelskiego Sejmu Unii. Rok 1569, wyd. A.T. Działyński, Poznań 1856, s. 118.

87 Por. np. NIAB, f. 1744, 5, k. 351, 365v.

88 Zob. Uniwersał kolski 1572, ASWP, t. 1, cz. 1, s. 6. Por. ostry zakaz posiadania „wszelkiej strzelby” na elekcji; Zbiór pamiętników do dziejów, t. 3, s. 27. 
z miejsca przegrywać swą sprawę. Za zuchwalstwo, „wszeteczne” słowa wobec sądu lub innych osób, przerywanie, wrzaski, wołanie groziła kara porządkowa na rzecz sądu w wysokości 3 grzywien, pod groźbą następnych 14 grzywien w razie nieuiszczenia jej. Dobycie korda w sądzie lub, co gorsza, ranienie kogoś zagrożone było karą na gardle, a gdyby nie udało się schwytać sprawcy - konfiskatą jego dóbr ${ }^{89}$.

Zadbano również o „przepisy wykonawcze”. Egzekucję wyroków sądów kapturowych powierzono poszczególnym starostom sądowym. Banitę ścigać miał starosta wraz „z pany deputaty” i pospolitym ruszeniem ziemskim („ziemią nań ruszyć”). Zastrzeżono jednak możliwość „użycia” innych starostów z województwa, gdyby ten właściwy zaniechał swoich obowiązków. Takowemu urzędnikowi groziła kara 200 grzywien, można było go też pozwać z tytułu complicitate banniti - za pomoc banicie $^{90}$. Aby usprawnić wymiar sprawiedliwości, zobowiązano też starostów do utrzymywania podstarościch ${ }^{91}$. Do powinności starosty sądowego czasu bezkrólewia należało także inwentaryzowanie dóbr po zmarłym plebanie w parafii, gdzie podawcą był król. Odniesiono się do dekretów poprzednich sesji sądowych, potwierdzając ich prawomocność ${ }^{92}$. Zastrzeżono, że egzekucja ma przebiegać według norm statutowych oraz obecnie uchwalonych, nie zaś według uniwersału kolskiego. Wielkopolanie ustanowili bowiem tryb egzekwowania wyroków pospolitym ruszeniem, z wojewodą i kasztelanami, a także kary dla szlachty za niestawiennictwo. Na Podlasiu możliwość zwoływania zbrojnej szlachty dano starostom, nie wspomniano też o karaniu nieobecności ${ }^{93}$. Tymi zapisami kończył się pierwszy dokument, opatrzony jeszcze formułą przejętą z konfederacji generalnej - „co wszytko obiecujemy sobie ziścić i z potomki swemi, sub fide, honore et conscientiis nostris [pod wiarą, czcią i sumieniami naszymi], teraz i na potomne czasy"94.

${ }^{89}$ Zob. konstytucja z 1505 r. De inhonorato judicio, w: VC 1/1, s. 158; NIAB, f. 1708, 202, k. 483v; por. Uniwersał kolski 1572, ASWP, t. 1, cz. 1, s. 7.

90 Por. Uniwersał kolski 1572, ASWP, t. 1, cz. 1, s. 6-7; Zbiór pamiętników do dziejów, t. 3, s. 25; VC 1/1, s. 169; por. VC 2/2, s. 69.

${ }^{91}$ Konfederacja woj. podlaskiego 1573, NIAB, f. 1708, 202, k. 484; por. Konfederacja woj. podlaskiego 1587, NIAB, f. 1706, 11, k. 143v; por. Akta unii, s. 204; VC 2/1, s. 253.

92 Por. podobne zapisy z lat 1575 i 1587: Ordynacja sądów woj. podlaskiego, Drohiczyn, 13 I 1575, AGAD, Ks. gr. miel. 1, k. 78; Konfederacja woj. podlaskiego 1587, NIAB, f. 1706, 11, k. 144.

${ }^{93}$ Zob. ASWP, t. 1, cz. 1, s. 6-7; Ś. Orzelski, op. cit., t. 1, s. 15; por. E. de Noailles, op. cit., t. 3, s. 164. W 1575 r. pojawiły się już kary dla nieobecnych, zob. AGAD, Ks. gr. miel. 1, k. $78 \mathrm{v}$.

${ }_{94}$ Por. VC 2/1, s. 307. 
Nie mniej ciekawe jest drugie pismo, „Pobory i porządek jachania na elekcją" "95. Zgodzono się w nim „z miłości przeciw Rzeczypospolitej” na podatki ustanowione przez konwokację. Zawarowano jednak, aby poborcy zawitali do szlachty i jej poddanych dopiero po powrocie z elekcji. Natomiast miasta i Żydzi podlegali poborowi ex nunc. Zebrane pieniądze winny pozostać na miejscu ${ }^{96}$. Poborcami obrano w ziemi drohickiej komornika ziemskiego Piotra Bujnę, w bielskiej stolnika podlaskiego P. Gołasza Mościckiego, a w mielnickiej - sędziego grodzkiego W. Biernackiego. Uchwalono także pobór dla posłów na przeszłą konwokację, którzy tam „swym kosztem służyli”, w wysokości 4 gr „z dziesiąciu włók albo z konia" ${ }^{97}$. Wiązało się to chyba $\mathrm{z}$ faktem, że zjazd konwokacyjny interpretowano jako instytucję odmienną od sejmu. Posłowie z Podlasia od 1569 r. dostawali bowiem „strawne” ze skarbu ${ }^{98}$. Zbieranie pieniędzy „z konia” było zwyczajem powstałym jeszcze w końcu lat czterdziestych $^{99}$. Nie była to tylko specyfika Podlasia, gdyż podobne mechanizmy istniały w innych częściach Wielkiego Księstwa ${ }^{100}$. W ziemi bielskiej już w 1549 r. uchwalono składkę na „ekspensa” posłów, co powtarzano potem wielokrotnie ${ }^{101}$. W praktyce jednak ściąganie nawet tak niewielkiej opłaty szło wśród ubogiej szlachty opornie, m.in. dlatego posłów wybierano zwykle spośród urzędników i majętniejszych obywatelii ${ }^{102}$.

Uchwałą konfederacji zobowiązano szlachtę gniazdową do wybrania spośród siebie z każdych 10 włók i wysłania na elekcję „na dobrym koniu człowieka między sobą na to najsposobniejszego", któremu z każdej włóki miano dać po 1 zł na „strawę"103. Każdy, kto by nie chciał łożyć na

${ }^{95}$ Konfederacja woj. podlaskiego 1573, NIAB, f. 1708, 202, k. 484-484v.

96 Por. Ś. Orzelski, op. cit., t. 2, s. 203-204.

${ }_{97}$ Konfederacja woj. podlaskiego 1573, NIAB, f. 1708, 202, k. 484v.

98 Zob. Akta unii, s. 204; L. Kolankowski, op. cit., s. 134, 136, 138.

99 Dokumenty, t. 1, s. 532; Biblioteka Uniwersytetu Warszawskiego, rkp. 154, s. 42 43,56 .

100 Zob. A.B. Zakrzewski, Sejmiki Wielkiego Księstwa Litewskiego XVI-XVIII w. Ustrój i funkcjonowanie: sejmik trocki, Warszawa 2000, s. 139-145; A. Rachuba, Diety poselskie w Wielkim Księstwie Litewskim XVI-XVII w. na przykładzie sejmiku żmudzkiego, w: Z dziejów kultury prawnej, red. A. Rosner i in., Warszawa 2004, s. 599-606; A. Radaman, Uchwała sejmikowa powiatu nowogródzkiego z 1568 r. a system finansowania posłów sejmowych Wielkiego Księstwa Litewskiego, w: Litwa w epoce Wazów, red. W. Kriegseisen, A. Rachuba, Warszawa 2006, s. 157-174.

101 Posłom na sejm wileński (1565-1566) i lubelski (1569) przyznano po 6 gr z konia/10 włók, na grodzieński (1567 lub 1568) - po 4 gr; NIAB, f. 1744, 1, k. 372v; f. 1708, 5, k. 16v, 42, 75, 511v-512; 6, k. 30v, 50v-51, 128v, 130, 232, 570v, 573v; ANK, ZZG 55, s. 303.

102 Zob. np. NIAB, f. 1744, 4, k. 72v, 247.

$103 \mathrm{Na}$ następnej elekcji zmniejszono tę opłatę do 40 gr z włóki, zob. M. Kiszka do szlachty podlaskiej, Grochów, 5 XI 1575, NIAB, f. 1706, 12, k. 711. 
wyprawę, podlegał karze 14 grzywien, otwarto też drogę sądową o dochodzenie poniesionych kosztów od „niedbałych” częśników. Dozwolono jednak uboższym już z miejsca elekcji odesłać część pocztu do domu. Tak jak w uchwale z Mielnika, obowiązki majętniejszej szlachty i urzędników wyglądały inaczej niż w przypadku „drobnej braci”. Ci pierwsi na elekcję „powinni jachać tym kształtem, jako jest w artykułach opisany” ${ }^{104}$. Chodzi tu o wytyczne z konwokacji, gdzie wprowadzono ograniczenia w uzbrojeniu i wielkości pocztów, które miały zapobiec tumultom na polu elekcyjnym $^{105}$. Wyłączeni z ekspedycji byli ci „teraz dla potrzeby doma [na Podlasiu] zostawieni" oraz osoby zwolnione odeń przez dawne prawa ${ }^{106}$. W czasie wypraw zwyczajowo zostawiano w ziemi bielskiej szlachciców do pilnowania skrzyń z księgami oraz przywilejami ziemskimi ${ }^{107}$.

W odpowiedzi na wezwanie, „aby wszyscy w domach swoich pogotowiu byli, jako do potrzeby ruszyć się byli powinni, gdzie się kolwiek gwałt a potrzeba okaże"108, na Podlasiu uchwalono „okazowanie” szlachciców pozostałych na miejscu. Mianowicie - „z dymu” oraz „tak właśnie, jakoby na wojnę jachać mieli", a za kwit popisowy powinno się brać nie więcej niż po półgroszku. Identyczną stawkę ustalono w $1544 \mathrm{r}^{109}$ „Popis” przeprowadzić mieli chorążowie - bielski J. Brzóska oraz drohicki i mielnicki A. Hlebowicz (w 1544 r. było to zadaniem starostów) ${ }^{110}$. Na jego miejsce dla ziem drohickiej i mielnickiej wyznaczono Drohiczyn, dla bielskiej - Suraż. Bardzo istotna była data - dzień rozpoczęcia sejmu (5 kwietnia). Chorążym powierzono „zupełną moc” w dowodzeniu rycerstwem „według zdania ich i potrzeby województwa”, przydano im także spośród przedniejszej szlachty po czterech pomocników. Tym przykazano, by „we wszytkiem panów chorążów [!] swych jako hetmanów, na ten czas tylko, posłuszni" byli. Szlachta musiała wpisać się w rejestr i odebrać

104 Konfederacja woj. podlaskiego 1573, NIAB, f. 1708, 202, k. 485.

105 Zbiór pamiętników do dziejów, t. 3, s. 27-28.

106 Por. rozwiązania z Mazowsza (1572), E. Dubas-Urwanowicz, Koronne zjazdy, s. 156.

107 Dokumenty, t. 1, s. 532; I.T. Baranowski, Podlasie w przededniu Unii Lubelskiej. Trzy studia z dziejów społeczno-ekonomicznych, PH 7, 1908, z. 1, s. 70; zob. przykłady z lat 1561, 1562 i 1567; NIAB, f. 1708, 3, k. 477v (kopia: AGAD, Kapicjana 9, k. 203; cyt. za: J. Siedlecki, Kancelaria ziemi bielskiej w Brańsku w XVI-XVIII wieku, „Zeszyty Naukowe Filii UW w Białymstoku", z. 66, Humanistyka 12, dział H - Prace Historyczne, 1988, s. 29-30, 51); 4, k. 309v-310; 5, k. 506v.

108 Zbiór pamiętników do dziejów, t. 3, s. 25.

109 Konfederacja woj. podlaskiego 1573, NIAB, f. 1708, 202, k. 485; Russkaâ Istoričeskâ Biblioteka [dalej: RIB], t. 30, S.-Peterburg 1914, kol. 110-112, 304-310; A. Jabłonowski, Podlasie, cz. 2, Warszawa 1909, s. 199.

110 Zob. Urzędnicy, t. 8, s. 67, 100. 
kwity. Obowiązek uczestnictwa w okazowaniu rozciągnięto na poddanych królewskich wsi i miast, skąd miano wybrać z każdego domu jednego mężczyznę odpowiedniego do wojaczki. Tym, którzy nie stawiliby się wyznaczonego dnia na miejscu, nie odebrali kwitu lub okazali nieposłuszeństwo chorążym, groziła nawet utrata majątku. Dokument kończyło napomnienie dla starostów sądowych, by niezwłocznie publikowali treść uchwał przez woźnych po parafiach, by nie dać pretekstu do ewentualnego wymawiania się o niewiedzą. Trudno nie łączyć tegoż okazowania z chęcią dania odporu litewskim dążeniom do rewindykacji Podlasia.

Konfederacja drohiczyńska była właściwie pozbawiona postulatów politycznych. Podlasianie przyjęli chyba bez większych kontrowersji postanowienia konwokacji. Nie protestowano przeciw poborom, a zatrzymanie ich we własnym województwie zgadzało się z uchwałami innych sejmików ${ }^{111}$. Skupiono się mocno na lokalnej pragmatyce: sądach, bezpieczeństwie, sposobie wyprawienia się na elekcję. Mimo braku stanowczych deklaracji odnoszących się do litewskich żądań, jak uprzednio (wrzesień 1572), częste podkreślanie przynależności do Korony oraz uchwały na temat obrony i pospolitego ruszenia stanowią ich ekwiwalent.

Z tekstu konfederacji nie sposób dociec, jaki był stosunek ogółu miejscowej szlachty do gwarancji pokoju między „rozróżnionymi w wierze”. Protestację sprzeciwiającą się temu punktowi wnieśli Mazurzy, podobną opinię wyraziła też szlachta płocka ${ }^{112}$. Maurycy Dzieduszycki wśród przeciwników uchwały tolerancyjnej wymienił jednym tchem (bez podania źródła) obok trzech województw Mazowsza także Podlasie ${ }^{113}$. Pominięcie tej kwestii w konfederacji z Drohiczyna było może wynikiem kompromisu, gdyż protestanci posiadali tu znaczne wpływy. Szlachta podlaska od lat (1547-1568) zabiegała o uwolnienie od egzekucji starościńskiej wyroków duchownych, co można wiązać zarówno z postępami reformacji, jak i z częstymi sporami katolików z duchowieństwem, np. o dziesięciny lub obsadę probostw ${ }^{114}$. Pokój religijny Podlasianie zawarowali natomiast expressis verbis w kapturze po śmierci Stefana Batorego ze stycznia $1587 \mathrm{r}^{115}$

111 E. Dubas-Urwanowicz, Koronne zjazdy, s. 53.

112 Ibidem, s. 56; J.A. Gierowski, Sejmik Generalny Księstwa Mazowieckiego na tle ustroju sejmikowego Mazowsza, Wrocław 1948, s. 67-68; M. Korolko, op. cit., s. 73-74; R. Zieliński, Województwo płockie w czasie bezkrólewi i na elekcjach, cz. 1, „Notatki Płockie” 3, 1958, 9, s. 5.

113 M. Dzieduszycki, Piotr Skarga i jego wiek, t. 2, Kraków 1869, s. 79.

114 Dokumenty, t. 1, s. 533-544; I.T. Baranowski, Podlasie, s. 58-59, 71, 73. „Wojny kolatorskie" można prześledzić np. w parafii Jabłonka Kościelna, AD Siedlce, D 11, D 13, D 15, passim.

115 Konfederacja woj. podlaskiego 1587, NIAB, f. 1706, 11, k. $143 \mathrm{v}$. 
Uchwała z Drohiczyna z 1573 r. nosi wyraźne piętno postanowień z Koła. Wpływy wielkopolskie przenikały tutaj via Mazowsze, zresztą Podlasianie z pewnością naśladowali swoich mazowieckich „kuzynów”, którzy proces integracji z Koroną rozpoczęli kilka dekad wcześniej. Silne powiązania wielkopolsko-mazowieckie E. Dubas-Urwanowicz uznała za przejaw „niedojrzałości politycznej”, w czym „Mazowsze w sposób wyraźny odstawało od pozostałych prowincji Korony"116. Trudno oprzeć się wrażeniu, że jest to sąd negatywnie wartościujący, oparty na wciąż pokutującym stereotypie. Inna rzecz, czy widziano wówczas w Mazowszu samodzielną prowincję, czy też część wielkopolskiej. Po roku 1569 szlachcice bielscy uważali się za „przywróconych” do Wielkopolski ${ }^{117}$. Dzięki badaniom Jolanty Choińskiej-Miki nad epoką późniejszą wiemy, jak silne u szlachty mazowieckiej były legalizm i akcentowanie „,braterskiej" zgody ${ }^{118}$. W moim przekonaniu postawa Mazowsza i Podlasia nie była oznaką „politycznego niedorozwoju”, lecz wynikała ze świadomego wyboru i dążeń integracyjnych, których swoistym przeciwieństwem był separatyzm pruski czy litewski ${ }^{119}$.

Inaczej niż w uniwersale kolskim, w zapisach podlaskiej konfederacji rozgraniczono działania pospolitego ruszenia na policyjne, w których wodzem miał być starosta (de facto podstarości), oraz związane z obronnością, kiedy prym wiódł chorąży. W obu przypadkach jednak „nadzwyczajne kompetencje" urzędników były równoważone przez kolegialność - tak w sądzie deputackim, jak i w „radach wojennych”. Struktura pospolitego ruszenia podlaskiego, z silną pozycją chorążych, a jednym tylko kasztelanem, wciąż nosiła piętno niedawno zakończonej „epoki litewskiej”. Wprowadzenie instytucji pomocników chorążego była zapowiedzią wytworzenia się w następnym stuleciu kadry dowódczej pospolitego ruszenia wzorowanej na armii zaciężnej ${ }^{120}$. Prócz chorążego-pułkownika

116 E. Dubas-Urwanowicz, Koronne zjazdy, s. 83, 130, 145, 164-165.

117 Zob. mowa kasztelana czerskiego Zygmunta Wolskiego, w: Diariusz zjazdu w Kole za pierwszego bezkrólewia, wyd. Z. Bodniak, „Pamiętnik Biblioteki Kórnickiej”, z. 1, 1929, s. 90; por. wymowne wahanie autora (Wielkopolanina zresztą) Modus eligendi novi Regis et ratio procedendi tempore Interregni laudata a supremo consilio, w: BC 80, s. 718; E. Kalinowski, op. cit., passim.

118 J. Choińska-Mika, Sejmiki mazowieckie w dobie Wazów, Warszawa 1998, s. 96-97, $111,149$.

119 Mazurzy silnie akcentowali trwanie przy jedności i „unii” w swej konfederacji z 1572 r. (BC 2724, s. 347); por. E. Dubas-Urwanowicz, Koronne zjazdy, passim; eadem, Bezkrólewie - czas integracji czy podziałów?, PH 85, 1994, z. 1/2, s. 35-43.

120 Zob. E. Kalinowski, Strachy na Lachy - na Podlasiu: szlachta ziemi bielskiej w walce z powstaniem Chmielnickiego (1648-1649), PH 105, 2014, z. 1, s. 21-58; K. Łopatecki, Organizacja, prawo i dyscyplina w polskim i litewskim pospolitym ruszeniu (do połowy XVII wieku), 
ważną rolę odgrywali tu rotmistrzowie parafii, których „przodkami” byli owi pomocnicy dowódcy. Pomysł zastępowania kasztelanów w dowodzeniu powiatami przez doświadczonych w służbie wojennej szlachciców pojawił się także w tekście z 1572 r. z terenu Wielkopolski121.

Tymczasem akcja podjęta na marcowych sejmikach koronnych zakończyła się sromotną klęską, gdyż litewskie listy dotarły już po skończeniu obrad najważniejszych z nich. Zdążający pod Warszawę Litwini postanowili więc uczynić „punkt zborny” w Bielsku. Wynikało to nie tylko z faktu, że tędy przebiegał ich szlak, lecz miało też stanowić czytelny sygnał o ich pretensjach do Podlasia. Na początku kwietnia 1573 r. zebrało się tu co najmniej kilku czołowych senatorów litewskich. Ci wystosowali list z apelem o przesunięcie daty rozpoczęcia sejmu. Henryk Lulewicz słusznie domyślał się, że przyczyną zwłoki był „zbyt skromny orszak litewski, zupełnie nieprzystający do aspiracji politycznych tamtejszej elity senatorskiej”, trudno jednak zgodzić się, że czekali „na gremialny wyjazd pod Warszawę szlachty podlaskiej, żeby stawić się na polu elekcyjnym w liczniejszym towarzystwie"122. Stanowisko Podlasian i Litwinów wobec rewizji postanowień z 1569 r. było zasadniczo rozbieżne, trudno więc wyobrazić sobie ich wspólnie maszerujących ku Warszawie. Fakt ujęcia się za tymi, „którzy w ziemi podlaski [!] osiadłości swe mają", aby nie byli karani za to, że nie uczynili zadość „okazowaniu”123, świadczy raczej o sporej nieufności. Litwini zdawali sobie sprawę, że - jak je pogardliwie ${ }^{124}$ określili „niejakie okazowanie stanów szlacheckich” było wymierzone przeciwko nim. Atmosfera w województwie podlaskim musiała być wówczas napięta. Pamiętano wszak sytuację sprzed czterech lat, gdy po włączeniu Podlasia do Korony panowie litewscy grozili wręcz siłową interwencją ${ }^{125}$.

Sejm elekcyjny rozpoczął się zgodnie z planem (5 IV 1573), co spóźnieni Litwini musieli z goryczą przełknąć. Niespełna tydzień później (13 kwietnia) dotarła już pod Warszawę znaczna część przedstawicieli Wielkiego Księstwa. Oficjalne upomnienie się o „zabrane” ziemie na sejmie miało miejsce 19 kwietnia. Po raz kolejny spotkało się to ze stanowczą odmową Korony ${ }^{126}$. Wobec porażki na drodze oficjalnej Litwini uchwycili się

Białystok 2013, s. 477-478, 509-510, 545-546; J. Maroszek, Dzieje województwa podlaskiego do 1795 roku, Białystok 2013, s. 427-429.

121 Modus eligendi, BC 80, s. 715-716. Pochodzenie autora zdradza niespotykany postulat elekcji w Piotrkowie.

${ }^{122}$ H. Lulewicz, op. cit., s. 133-134.

123 Akta zjazdów, t. 1, s. 72.

124 Zob. M. Korolko, op. cit., s. 73.

125 Dnevnik, s. 144-326; Źródłopisma, cz. 3, s. 66-156.

${ }^{126}$ H. Lulewicz, op. cit., s. 137-141; E. Dubas-Urwanowicz, Koronne zjazdy, s. 271. 
środków nieformalnych, wybierając bezpośrednie negocjacje z posłami kandydata francuskiego. W deklaracji Francuzów (26 IV 1573) znalazł się punkt, w którym obiecywano przywrócenie Litwie „ziem zabranych”. Postulowano w nim „przyjacielski” podział Podlasia z Koroną, mniej więcej na linii rzeki Nurzec. Polsce przypaść miała część należąca doń dawniej - chodziło o zachodnią połać tej krainy, odebraną niegdyś Mazowszu. Wspomniano też o pewnym „naddatku”, który panowie litewscy po „bratersku” i „przyjacielsku” zgadzali się oddać127. Do Litwy zamierzano „przywrócić" tereny ziemi bielskiej na północ od Nurca, a na wschód od skupisk drobnej szlachty. Litwinom zależało na królewszczyznach we wschodniej części województwa, zamieszkanej ponadto w znacznym stopniu przez ludność etnicznie ruską wyznającą prawosławie. Świadczy to o pewnym sukcesie polityki szlachty podlaskiej. Nie bez znaczenia była tu może obecność we francuskim orszaku słynnego Domine - Jana Krassowskiego, przemyślnego szlachcica rodem z Podlasia. Ten powróciwszy do kraju jeszcze przed śmiercią Zygmunta Augusta, w ostatnich miesiącach przebywał w rodzinnych stronach wśród drobnej braci, znał więc jej zapatrywania. To właśnie on został wysłany na Litwę przez Francuzów jeszcze w końcu 1572 r. ${ }^{128}$ Zachowała się także inna tajna deklaracja francuska w sprawie spornych ziem, z nieco późniejszą datą (30 IV 1573) ${ }^{129}$, skierowana do dygnitarzy województw wołyńskiego, kijowskiego i bracławskiego, którzy godzili się na ponowne złączenie z Litwą. Nie ma tam mowy o Podlasiu ani o dostojnikach podlaskich - co świadczy o ich nieprzejednaniu.

Według relacji cudzoziemskich zebranej na elekcji szlachty było ogółem ok. 40-50 tys., w tym 10 tys. Mazurów, choć zdaniem Jana Dzięgielewskiego tę ostatnią liczbę należałoby zredukować do ok. 3-4 tys. ${ }^{130}$ Tłumnie zgromadzona na polu elekcyjnym uboga szlachta, w swej masie katolicka, miała istotny wpływ na przebieg wyboru władcy. Głośno popierała kandydatury swych współwyznawców i kilkakrotnie ponawiała naciski

127 E. de Noailles, op. cit., t. 3, s. 399-402; H. Lulewicz, op. cit., s. 138-139.

128 S. Grzybowski, Krasowski (Krassowski) Jan (ok. 1530 - po 1573), PSB, t. 15, Wrocław 1970, s. 209-210. Wsie szlacheckie o nazwie Krasowo można znaleźć i w z. bielskiej, i w drohickiej. Zob. J. Choisnin, O elekcji Henryka Walezjusza na króla polskiego pamiętniki, tłum. W. Turski, Wilno 1818, s. 103, 169-255.

129 E. de Noailles, op. cit., t. 3, s. 402-404; H. Lulewicz, op. cit., s. 139.

130 J. Dzięgielewski, Sejmy elekcyjne, elektorzy, elekcje 1573-1674, Pułtusk 2003, s. 70; zob. J. Choisnin, op. cit., s. 176. Doszło tutaj do pomyłki w tłumaczeniu (por. tenże, Mémoires, s. 318), autor całkowitą liczbę zebranej szlachty oceniał na 40, nie 50 tys., podobnie jak jego rodak Blaise de Vigenère (La Description Du Royaume De Poloigne Et Pays Adiacens, Paris 1573, k. IIIv, XVI). Ten drugi pisał o ponad 10 tys. szlachciców posiadających drogocenne rzędy końskie i uprzęże (wartości 1-1,2 tys. escus). 
na przyspieszenie elekcji. Przeciąganie się sejmu rujnowało ubogich szaraków wyprawionych niemałym sumptem pod Warszawę. Z podobnych zresztą przyczyn także i Litwinom zależało na szybkim przystąpieniu do głosowania ${ }^{131}$. Pominięcie w pismach pamiętnikarzy Podlasian ${ }^{132}$ jest tylko pozorne. Wydaje się, że ówcześni obserwatorzy nie odróżniali ich od Mazowszan. Zgodnie z postanowieniami z roku 1569 - o ile podczas elekcji trzymano się sejmowej precedencji - stanowiska Podlasia wypadały pomiędzy jego mazowiecką „bracią”. Takie jest zresztą usytuowanie podlaskich suffragiów zachowanych z późniejszych elekcji133. W tłumie drobnej szlachty nie zawsze też odróżniano od mazowieckiego pokrewne mu województwa płockie i rawskie ${ }^{134}$.

Pomimo niedostatku źródeł można podjąć próbę ustalenia przybliżonej liczebności Podlasian wyprawionych na elekcję. Dysponujemy dwoma spisami wypraw pospolitego ruszenia ze schyłku „epoki litewskiej”. Z nich pierwsza opierała się na zasadzie „włócznej” (1565), druga - na „dymowej” czy może viritim (1567). Cennym materiałem porównawczym są dane dla ziemi bielskiej z XVII w. (1648-1649, 1651, 1670, 1697)135. Leszek Podhorodecki pisał o 3,4-3,5 tys. Podlasian wyprawionych pod Lwów (1621), lecz wydaje się, że przecenił ich liczebnośćc ${ }^{136}$. Warto wspomnieć obliczenia Łukasza Rusiniaka, prezentujące liczbę elektorów podpisanych na znanych suffragiach, głównie z XVII w., lecz trudno uznać je za miarodajne w tym przypadku ${ }^{137}$. Szlachta podlaska, która wybrała się

131 J. Choisnin, O elekcji, s. 207-208, 217, 228, 232; Ś. Orzelski, op. cit., t. 1, s. 104.

132 Zob. S. Gruszecki, Walka o władze, s. 27 (loc. cit.).

133 Zob. Akta unii, s. 203, 374; Dnevnik, s. 335; Źródłopisma, cz. 3, s. 77, 80-81; VL 4, s. $112 ; 5$, s. $159-160,455 ; 7$, s. $127-129$.

134 R. Zieliński, op. cit., s. 6. Sędziwój Czarnkowski pisał 20 maja 1573 r. Zofii Jagiellonce, że do popierających elekcję Francuza Mazurów przyłączyły się woj. płockie i rawskie (Jagiellonki polskie w XVI wieku, wyd. A. Przezdziecki, t. 4, Kraków 1868, s. 58), Władysław Smoleński zaś (Udział szlachty mazowieckiej w elekcjach królów, PH 1, 1905, z. 1, s. 59), cytując to źródło, mimochodem dodał do nich i podlaskie.

135 AGAD, Ks. gr. brań. 44, k. 56-75; ANK, ZZG 623, s. 1-31; NIAB, f. 1708, 141, k. $692-$ 695v; E. Kalinowski, Kalinowscy herbu Ślepowron w XVII wieku, Warszawa 2013, s. 62; idem, Strachy na Lachy, passim. Por. K. Łopatecki, op. cit., s. 510.

136 L. Podhorodecki, Chocim 1621, Warszawa 2008, s. 154. Zastosowano wówczas zasadę „włóczną”, uzupełnioną możliwością wystawienia jeźdźca „po husarsku” z 20 włók; zob. NIAB, f. 1708, 107, k. 207, 230.

137 Wg tych obliczeń w kolejnych elekcjach Podlasian podpisało się: 149 (rok 1632), 197 (1648), 431 (1669), 288 (1674), 215 (1697), 295 (1764). Zob. Ł. Rusiniak, „Podlascy elektorowie królów", Warszawa 2012, praca magisterska napisana w Instytucie Historycznym UW pod kierunkiem M. Kopczyńskiego, s. 18, tab. 1. Tylko część z tych elekcji Podlasianie odbyli pospolitym ruszeniem, poza tym podpisy nie oddają liczby szlachciców obecnych na nich od początku, por. M. Kopczyński, J. Brodacki, Obywatele czy tłum? 
na elekcję w 1573 r. - ze wszystkich trzech ziem łącznie - mogła liczyć moim zdaniem od ok. 1 tys. do maksymalnie 1,5 tys. jeźdźców, lecz bliżej chyba tej pierwszej liczby ${ }^{138}$. Pamiętając o szacunkach dotyczących liczby ogółu „Mazurów” sensu largo, przybysze z Podlasia mogli więc stanowić na elekcji od 10 do nawet $25 \%$ tychże.

Aleksander Gwagnin w 1578 r. obliczał całkowite możliwości mobilizacyjne Podlasian na ok. 20 tys. ludzi139. Bliższą rzeczywistości wydaje się, i tak dość wysoka, liczba szlachciców spisanych w 1567 r. - niespełna 9 tys. ${ }^{140} \mathrm{Na}$ jej podstawie można podjąć próbę oszacowania siły szlachty pozostałej w 1573 r. na miejscu, która miała wziąć udział w „okazowaniu". Zatem w ziemiach drohickiej i mielnickiej łącznie po wyprawieniu ok. 600-800 jeźdźców na elekcję zostałoby jeszcze blisko 4 tys. zdolnych do walki szlachciców, nie licząc piechoty z dóbr królewskich. W ziemi bielskiej natomiast po wyjeździe 450-700 konnych można by jeszcze zebrać do 3,5 tys. zbrojnej szlachty, także pamiętając o kontyngencie z królewszczyzn. Jeśli więc postanowienia konfederacji były egzekwowane z należytą starannością, siły zaangażowane w obronę „przynależności koronnej" Podlasia mogły być znaczące. Abstrahując od stanu uzbrojenia i karności wojskowej, wystarczyło to do demonstracji zbrojnej i politycznej, jaką tutejsze elity chciały wówczas przeprowadzić.

Ze względu na braki źródłowe o realizacji uchwał przedelekcyjnych można wnosić tylko dzięki pojedynczym wzmiankom z terenu ziemi bielskiej. Wydatki na wikt dla elektorów okazały się tam niejednokrotnie źródłem napięć. Np. gdy dziedzice ze wsi Poraje (Gdale-Porajewo) domagali się (29 III 1573) od sąsiadów ze wsi Bolesty 5 zł na koszty z tytułu 5 włók, ci zaproponowali inne rozwiązanie. Chcieli, by szlachta z Porajów tym razem wyprawiła jeźdźca swoim sumptem, a na następne pospolite ruszenie to samo zrobią Bolestowie. Rzeczywiście, według zachowanych

Elektorzy władców Rzeczypospolitej z województwa mazowieckiego w latach 1632-1764, PH 106, 2015, z. 1, s. 124.

138 Swoje szacunki opracowałem, porównując „stan idealny”, jaki można odtworzyć dzięki źródłom dla z. bielskiej (ok. 600-700 wg danych z 1670 r.), ze „stanem faktycznym" - liczbą jeźdźców rzeczywiście spisanych, zarówno w 1565 (475), w 1651 (ok. 500-550), jak i w 1670 r. (446). Liczba z 1697 r. (397) może być zaniżona ze względu na nie do końca jasne zapisy i ew. wynikające stąd omyłki w rachunku. Podpisów z całego Podlasia pod elekcją 1697 r. złożono zaledwie 215 (Ł. Rusiniak, op. cit., s. 18). Dysponując dla z. drohickiej i mielnickiej jedynie danymi z 1565 r. $(510+65)$, „stan idealny" można tylko szacować przez analogię do liczb z z. bielskiej (i ostrożne doliczenie „średniego odsetka nieobecnych”). Sejmik brański stwierdzał, że z. bielska wystawiła w 1648 r. 800 koni, a mielnicka ledwie 50, zob. NIAB, f. 1708, 37, k. 458v.

139 A. Gwagnin, Sarmatiae Europae descriptio, Cracoviae 1578, k. 69v.

140 RIB, t. 33, od. 1, cz. 3, S.-Peterburg 1915, kol. 1377. 
popisów z 1670 i 1697 r. Gdale-Porajewo miało obowiązek wystawić pół konia, Bolesty zaś - półtora ${ }^{141}$. W takiej sytuacji dzielono się kosztami na wyprawienie drugiego jeźdźca. Z kolei Mikołaj Grodzki, kiedy jego współdziedzice z Grodzkich dali mu na drogę do Warszawy zaledwie 80 gr, prosił, aby obecni przy fakcie woźny i dwóch szlachciców (wszyscy zresztą Grodzcy) zeznali o tym przed księgami, co też uczynili ${ }^{142}$. Sprawa pomiędzy wysłanym na elekcję przez ziemian z Pierzchał Michałem z sąsiednich Bagieńskich a jego „pracodawcami” trafiła przed sąd, ci bowiem w ogóle nie wywiązali się z zawartego kontraktu i nie wypłacili obiecanych $10 \mathrm{z}^{143}$. Występowały także sytuacje odwrotne - kiedy reszta mieszkańców dopominała się zwrotu pieniędzy od wyprawionego szlachcica. Tak było w przypadku Pawła z Wnor-Wypych, Niemiery vel Erazma z Gołaszy-Górek oraz Wojciecha z Łap-Wągli. Sąd deputacki oddalił jednak te roszczenia, doceniając fakt, że pozwani byli na elekcji ${ }^{144}$. Prawdopodobnie powodem takich pretensji były klauzule w umowach (pisemnych lub ustnych) zobowiązujące elektorów do rozliczenia się z wydatków po powrocie. Przykłady tego zawierają kontrakty przed wyruszeniem przeciw Turkom $(1621)^{145}$. Niedobór gotówki zmuszał niekiedy ubogą szlachtę do zastawiania ziemi, aby podołać wydatkom. Postąpili tak trzej bracia z Drągów, oddając w zastaw stryjowi 9 zagonów za kwotę 8 zł, które mieli obrócić zarówno na pokrycie kosztów wyprawy, jak i na swe „domowe” potrzeby ${ }^{146}$. Podobna motywacja kryła się może za znaczną częścią transakcji odnotowanych w tym roku, jednak tylko wyjątkowo podawano ich powody ${ }^{147}$.

Trudno powiedzieć, jaka część Podlasian dotrwała do skończenia elekcji, można jednak sądzić, że jej przedłużanie się powodowało pewne ubytki w szeregach ${ }^{148}$. Niewiele, również ze względu na szczupłość źródeł, wiadomo o udziale w wyborze nowego króla miejscowych dygnitarzy, urzędników i bogatszej szlachty. Uczestniczyli w niej obaj senatorowie

${ }^{141}$ NIAB, f. 1708, 202, k. 126; AGAD, Ks. gr. brań. 44, k. 62v; ANK, ZZG 623, s. 13 (1697).

${ }_{142}$ AGAD, Ks. gr. brań. 5, k. 570v.

143 NIAB, f. 1708, 202, k. 395b.

144 Ibidem, k. 672, 676.

145 Ibidem, 107, k. 230-230v, 253v.

146 Ibidem, 202, k. 472v.

147 Już w Łowiczu (1572) zakładano wzrost zapotrzebowania na pieniądze w związku z przewidywaną wyprawą, podobnie pod Warszawą; zob. Skarbiec, t. 2, s. 22; BC 2724, s. 352; transakcje związane z wydatkami na wojnę znajdujemy we wcześniejszych księgach brańskich, np. NIAB, f. 1708, 3, k. 497v, 512v, 514v, 516v.

148 Być może doświadczenia tej elekcji, zwłaszcza problemy z aprowizacją, zniechęciły część szlachty do udziału w następnej; M. Kiszka do szlachty podlaskiej, Grochów, 5 XI 1575, NIAB, f. 1706, 12, k. 711-711v. por. uchwała z. bielskiej, Suraż, 8 V 1587, NIAB, f. 1706,11, k. 205. 
podlascy, gdyż ich podpisy można znaleźć pod dokumentami elekcyjnymi ${ }^{149}$. Na początku maja (między 4 a 6) wrócił z Warszawy podkomorzy ziemi bielskiej T. Brzozowski, którego przybycie przyspieszyły może wieści o najeździe na jego dobra Dubicze i poranieniu syna Krzysztofa ${ }^{150}$. $\mathrm{Na}$ sejmie był chyba sędzia ziemski W. Wyszkowski, skoro protestację w sprawie napadu na swego poddanego wniósł dopiero 2 tygodnie po zdarzeniu (miało miejsce 10 maja) ${ }^{151}$. Jeszcze 1 maja ok. 30 konnych splądrowało dobra Macieja Proszeńskiego w Proszance. Jeden z prowodyrów, Jakub Krassowski, był na elekcji ${ }^{152}$, można się więc domyślać, iż resztę „oddziału” także stanowili pospolitacy. Kiedy zaś na elekcję wyjechał Fryderyk Brzóska, „zły sąsiad” Grzegorz Kikolski zamęczył mu wołu. Brzóska był bratem chorążego bielskiego, toteż pod Warszawę wyprawił się zapewne niejako „w zastępstwie” Jerzego, którego zatrzymały obowiązki ${ }^{153}$. Znana jest spora aktywność Andrzeja Jałbrzyka Wyszyńskiego na następnej elekcji, lecz nie wiadomo, czy podobnie było wiosną $1573 \mathrm{r}$. Widać jednak, że niedługo potem jego kariera przyspieszyła, pod koniec roku uzyskał pisarstwo grodzkie brańskie po Michale Wyszkowskim, potem został poborcą ziemi bielskiej za rok 1573, a w 1574 r. lustratorem dóbr stołu królewskiego na Podlasiu ${ }^{154}$. Na sejm elekcyjny wybrała się też delegacja miast królewskich - Bielska, Brańska, Suraża, Drohiczyna, Łosic i Mielnika, skarżąc się na swych starostów o przeciwne przywilejowi koronnemu obciążenia. Mandaty uzyskane przez mieszczan od sejmu, podobne w treści, noszą tę samą datę -22 kwietnia. Goniądz otrzymał nieco odmienne od pozostałych pismo datowane 30 kwietnia ${ }^{155}$. Skutek ich był jednak krótkotrwały, skoro skargi powtarzały się i później.

149 Fragmenty oblaty z Brańska można znaleźć obecnie aż w 3 księgach: NIAB, f. 1708, 202, k. 282-299v (część zasadnicza); NIAB, f. 1744, 5, k. 407-407v oraz AGAD, Ks. gr. brań. 6, k. 185-185v (pojedyncze karty).

150 NIAB, f. 1708, 202, k. 434-435v.

${ }^{151}$ Ibidem, k. 376v-377.

152 Ibidem, k. 406v, 415-415v, 424. Rodzina Krassowskich należała do udzielających się w życiu publicznym. Mroczek Krassowski posłował z z. bielskiej w 1532 r.; jego syn Jan - w 1551, drugi zaś, Andrzej, był komornikiem ziemskim. Trzeci z braci, Walenty, ojciec m.in. Jakuba i Mikołaja, zmarł w końcu 1572 r., zostawiając krótki testament; zob. ibidem, k. 343v-345; I.T. Baranowski, Podlasie, s. 67-69.

153 NIAB, f. 1708, 202, k. 647. Relację między braćmi dobrze oddaje jeden z zapisów, który Fryderyka nazywa sługą (famulus) chorążego; ibidem, k. 113.

154 Ś. Orzelski, op. cit., t. 2, s. 158, 213, 279-280; NIAB, f. 1708, 202, k. 666, 718; AGAD, Ks. gr. brań. 6, k. 450. Przy okazji dowiadujemy się, że w 1573 r. istniało 27 tomów ksiąg, zaczynających się od $1536 \mathrm{r}$.

155 NIAB, f. 1708, 202, k. 390-390v. Mieszczanie bielscy podali do oblaty również list M. Kiszki datowany z Użyk 10 sierpnia 1573 r.; ibidem, k. 610-610v; f. 1744, 6, k. 218v-219 (pismo dla Suraża wspomina o „główniejszym przywileju” Brańska, gdyż te 
Jednym z postanowień sejmu było potwierdzenie lokalnych konfederacji ${ }^{156}$. Po powrocie szlachty z elekcji mogły wreszcie wznowić działalność sądy kapturowe. Pierwsze roki rozpoczęły się w Brańsku zgodnie z zapowiedzią ok. dwa tygodnie po zakończeniu sejmu, tj. 8 czerwca 1573 r. Spośród deputatów brakowało chorążego Brzóski oraz starosty, urząd grodzki reprezentowali więc podstarości M. Mieński i sędzia grodzki Jakub Górski. Kolejne, zgodnie z przyjętym „rozkładem”, odbyły się za cztery „niedziele" - 6 lipca. Tym razem zjawił się chorąży, a zabrakło wojskiego. Również w Drohiczynie tego dnia urzędował kaptur, a jednocześnie odbywało się „leżenie ksiąg”157. Dwa tygodnie wcześniej (22 czerwca) otwarto księgi ziemskie w Surażu ${ }^{158}$. Jeszcze 18 czerwca, pod wpływem niepokojących wieści o zagrożeniu ze strony Moskwy, zebrał się w Drohiczynie sejmik wojewódzki, na którym obecny był wojewoda, zapewne inicjator zjazdu. Pomimo zapewnień woźnych drohickich, że informacja o nim dotarła do sąsiednich ziem, frekwencja szlachty, zwłaszcza bielskiej, musiała być znikoma. Uchwalono jednak konfederację, podkreślając jej związek i kompatybilność z tą „pośledniejszą”. Zdawano sobie sprawę atoli z ograniczonego mandatu zjazdu, stąd uchwały odnosiły się głównie do ziem drohickiej i mielnickiej, stanowiąc swego rodzaju poprawki do konfederacji z marca. Wyrażając solidarność z zagrożoną Litwą, i tu Podlasianie podkreślali swą przynależność do „Rzeczypospolitej Koronnej”, z którą w razie ataku „gwałtem ruszyć [--] powinni społem"159. Znane źródła milczą o reakcji Bielszczan na te uchwały.

W Brańsku sądzenie nagromadzonych spraw przeciągało się, dla przyspieszenia wymiaru sprawiedliwości postanowiono więc podzielić je parochiatim - z pierwszeństwem dla parafii odleglejszych od siedziby sądu. Gdy 8 lipca woźny ziemski, szlachcic Piotr Koćmier ogłaszał tę decyzję, wywołało to furię części zebranych. Ów omal nie został rozsiekany, gdyby nie wyratował go miejscowy burgrabia. Prowodyrzy tumultu podążyli za uciekającym do budynku sądu, który otoczywszy, odgrażali się sędziom ${ }^{160}$. Większość szlachty, w tym deputaci, stanęła murem za woźnym, a także za powagą i bezpieczeństwem sądów. Pod protestacją w tej

starostwa były wtedy połączone); AGAD, Ks. gr. miel. 1, k. 247-249; M. Baliński, T. Lipiński, Starożytna Polska, t. 3, wyd. F.K. Martynowski, Warszawa 1886, s. 407, 427, 431. Nie udało mi się odnaleźć mandatu dla Drohiczyna, jednak jego udział w akcji wydaje się oczywisty, por. Ś. Orzelski, op. cit., t. 3, s. 166-167.

156 VC 2/1, s. 325.

157 NIAB, f. 1715, 4, k. 339; 86, k. 119v.

158 NIAB, f. 1708, 202, k. 45v; f. 1744, 6, k. 138v.

159 Biblioteka Uniwersytecka w Warszawie, rkp. 354, s. 3-4.

160 AGAD, Ks. gr. brań. 5, k. 17-17v. 
sprawie podpisało się kilkudziesięciu szlachciców ${ }^{161}$. Ten incydent przyczynił się chyba do decyzji szlachty ziemi bielskiej o rezygnacji z sądów deputackich i odesłaniu spraw do grodu i ziemstwa ${ }^{162}$, które w sierpniu miały już pracować normalnie. Optymistyczne założenia z sejmu elekcji mówiły wszak o koronacji w październiku 1573 r., a sejmiki przed nią złożyły na 1 września. Kaptury winny działać właśnie „do przyjachania i postanowienia" elekta. Nie udało mi się odnaleźć niemal żadnych informacji o tych sejmikach na Podlasiu. Wiadomo jedynie, że jednym z posłów na koronację wybrano A. Jałbrzyka Wyszyńskiego, zapewne wtedy też został poborcą. Sąd deputacki w ziemi drohickiej działał natomiast jeszcze 20 października ${ }^{163}$.

Henryk Walezy przybył wreszcie do Polski w styczniu, a został koronowany w lutym 1574 r. Pod koniec marca przedstawiciele Litwy na sejmie po raz kolejny usilnie - i bezowocnie - domagali się przywrócenia odebranych im w 1569 r. ziem. „Ci zaś, o których skórę chodziło, oświadczali, że wolą pójść do niewoli raczej, niż wracać pod jarzmo Litwinów”. Król Henryk widocznie nie zamierzał dotrzymać warunków tajnego porozumienia sprzed roku - przeciwnie, potwierdził „przywilej podlaski” z 1569 r. Obsadził też kasztelanię podlaską po śmierci Kosińskiego, którą dostał M. Sawicki, a starostwo knyszyńskie nadał w atmosferze skandalu Janowi Zamojskiemu. W „konfirmacji praw” natomiast m.in. przywrócił zwyczajny bieg sądów ${ }^{164}$. Na wiele się to nie zdało, albowiem dwa miesiące później potajemnie uciekł z Polski, wywołując tym niemałe zamieszanie i nowe interregnum.

Odejście od sądów kapturowych można uznać za symboliczny koniec pierwszego bezkrólewia (czy pierwszej jego fazy) w ziemi bielskiej, przynajmniej w przekonaniu miejscowej szlachty.Jego bilans, pomimo pewnych zastrzeżeń, wypada ocenić pozytywnie. Przede wszystkim należy przy tym pamiętać o klęsce epidemii, która spadła na Podlasie równocześnie niemal z wieścią o śmierci królewskiej i była tu sroższa niż gdzie indziej. Spotęgowało to początkowy chaos i bezprawie, utrudniając szlachcie organizowanie się. Sądy kapturowe działające od 1573 r., zarówno „kolskie”, jak

${ }^{161}$ NIAB, f. 1708, 202, k. 87-88.

162 Ibidem, k. 151-162v, 672; por. Ordynacja sądów woj. podlaskiego 1575, AGAD, Ks. gr. miel. 1, k. 77v-78.

163 VC 2/1, s. 323-325; zob. NIAB, f. 1708, 2, k. 97-100v; 202, k. 582; AGAD, Ks. gr. brań. 6, k. 69v, 164-164v, 451, 514v; AGAD, Ks. gr. droh. I, 1, k. 415.

164 Ś. Orzelski, op. cit., t. 1, s. 262, 282-283; AGAD, Ks. gr. miel. 1, k. 78; 2, k. 3-4v, 6; Urzędnicy, t. 8, s. 135; VC 2/1, s. 333-334. 
i „drohiczyńskie”, także niezbyt dobrze radziły sobie ze wzmagającą się anarchią i eskalacją przemocy, czego najlepszym dowodem były lipcowe zajścia w Brańsku. Nic dziwnego zatem, że po wyjeździe Walezego dwa sejmiki województwa $(1574,1575)$ zdecydowały o pozostaniu przy sądownictwie z czasu panowania ${ }^{165}$, choć może liczono jeszcze na powrót króla.

Uchwalenie własnej konfederacji podniosło morale Podlasian i stworzyło precedens, do którego w ciepłych słowach odniesiono się po śmierci Batorego (1587). Mało tego, sporą część zapisów z Drohiczyna wręcz przepisano ${ }^{166}$. Energiczna akcja podlaskich senatorów ale też urzędników i wielu spośród szlachty przeciw litewskiemu rewizjonizmowi przyniosła dobre skutki. Wreszcie nawet sami Litwini skłonni byli zrzec się przynajmniej części ziem, których tak zażarcie bronili Podlasianie. Oczywiście, nie udałoby się to bez zdecydowanej postawy reszty Koroniarzy, którzy o żądaniach Litwy nie chcieli słyszeć. Racjonalny wymiar służby w pospolitym ruszeniu pozwolił także i uboższej szlachcie na posiadanie swych reprezentantów na elekcji. Zjazdy i gremialna wyprawa na elekcję pod Warszawę dodatkowo scementowały związek Podlasia z Koroną oraz wewnętrzną solidarność między trzema ziemiami, jak również pozytywnie wpłynęły na rozwój kultury politycznej i świadomości obywatelskiej Podlasian. Dzięki tej lekcji po ucieczce Walezego poradzono sobie już dużo sprawniej, a szlachta zaczęła przejmować inicjatywę od senatorów. Tak więc jesienią $1574 \mathrm{r}$. odbył się sejmik wojewódzki, czemu nie przeszkodziła nagła choroba i nieobecność M. Kiszki. Cztery lata później, w 1578 r., szlachta bielska wybrała własnego kandydata na pisarstwo ziemskie, nie oglądając się na gniew mającego nieco oligarchiczne ciągoty wojewody ${ }^{167}$.

\section{Streszczenie}

Szlachta województwa podlaskiego w czasie pierwszego bezkrólewia (1572-1574) odbyła szereg zjazdów partykularnych. Najważniejszym z nich był zakończony zawiązaniem konfederacji sejmik wojewódzki w Drohiczynie z 12 marca 1573 r.

Jeszcze w roku 1572 szlachcice podlascy na czele z senatorami i urzędnikami zebrali się dwukrotnie - we wrześniu w Mielniku i w listopadzie lub grudniu, być może w Drohiczynie. Uchwały ostatniego ze zjazdów, z 12 marca 1573 r., były wzorowane na uniwersale z Koła, jednak w większym stopniu uwzględniały lokalne potrzeby, wprowadzały też inne korekty. Postanowiono nie tylko jechać na elekcję pospolitym ruszeniem, opierając się na „zasadzie 10 włók”, ale zwołać też pod broń

165 Ordynacja sądów woj. podlaskiego 1575, AGAD, Ks. gr. miel. 1, k. 77-78v; E. Dubas-Urwanowicz, Koronne zjazdy, s. 69-70.

166 Zob. Konfederacja woj. podlaskiego 1587, NIAB, f. 1706, 11, k. 142v-145v.

167 ANK, ZZG 17, s. 297, 319-320. 
szlachtę pozostałą w domach na dzień rozpoczęcia sejmu. To posunięcie wymierzone było przeciwko zagrożeniu ze strony Litwinów, dopominających się powrotu Podlasia do Wielkiego Księstwa. Szlachta podlaska na sejmie wraz z Mazowszanami odegrała pewną rolę w wyborze francuskiego kandydata na tron. Jej determinacja w obronie przynależności koronnej Podlasia wpłynęła na rozstrzygnięcie tego sporu. Konfederacja szlachty województwa podlaskiego z 1573 r., choć w porównaniu z innymi częściami państwa zawarta bardzo późno, stanowiła osiągnięcie, do którego chętnie się potem odwoływano. Była wyrazem silnych dążeń unifikacyjnych, analogicznych do tych na Mazowszu, a przeciwstawnych do separatyzmów pruskiego i litewskiego czy konfliktu na linii Małopolska-Wielkopolska.

\section{The Political Activity of the Nobility of Podlasie during the First Interregnum}

At the time of the first interregnum (1572-1574) the nobility of the palatinate of Podlasie held a number of conventions, the most important being the palatinate sejmik (dietine) in Drohiczyn on 12 March 1573, which ended with the establishment of a confederation.

Members of the nobility from Podlasie, headed by senators and officials had already met twice in 1572 - in September in Mielnik and in November, or possibly December, in Drohiczyn. The resolutions passed at the latter convention (12 March 1573) were modelled on the proclamation from Koło, but took into greater consideration local needs and introduced a number of other corrections. It was decided not only to arrive at the convention by resorting to a levée en masse but also to announce a conscription of those members of the nobility who stayed at home on the day the Sejm was inaugurated. This procedure was directed against the threat posed by the Lithuanians who called for a restoration of Podlasie to the Grand Duchy. At the Sejm session the nobility of Podlasie, together with their counterparts from Mazovia, played a certain role in the election of the French candidate to the throne. The determined stand of the nobility concerning the defence of the affiliation of Podlasie to the Crown determined the solution of the dispute. The 1573 confederation of the nobility from the palatinate of Podlasie, albeit very late in comparison with other parts of the state, remained an accomplishment to which subsequent references were readily made. It expressed strong pro-unification strivings, analogous to those voiced in Mazovia and opposing Prussian and Lithuanian separatism or the conflict between Little Poland and Greater Poland.

Translated by Aleksandra Rodzińska-Chojnowska

\section{Bibliografia}

Baranowski, Ignacy Tadeusz. „Podlasie w przededniu Unii Lubelskiej. Trzy studia z dziejów społeczno-ekonomicznych". Przeglad Historyczny 7, nr 1 (1908): 48-74. 
Baranowski, Ignacy Tadeusz. „Sprawa szlachty poddańczej w starostwie Tykocińskim: z powodu artykułu ks. Zygmunta Dunin-Kozickiego". Przeglad Historyczny 13, nr 2 (1911): 248-254.

Budka, Włodzimierz. „Kto podpisał konfederację warszawską 1573 r.?”. Reformacja w Polsce 1, nr 4 (1921): 314-319.

Chmaj, Ludwik. Bracia polscy. Ludzie, idee, wpływy. Warszawa: Państwowe Wydawnictwo Naukowe, 1957.

Choińska-Mika, Jolanta. Sejmiki mazowieckie w dobie Wazów. Warszawa: Wydawnictwo Sejmowe, 1998.

Dubas-Urwanowicz, Ewa. „Bezkrólewie - czas integracji czy podziałów?”. Przegląd Historyczny 85, nr 1/2 (1994): 35-43.

Dubas-Urwanowicz, Ewa. Koronne zjazdy szlacheckie w dwóch pierwszych bezkrólewiach po śmierci Zygmunta Augusta. Białystok: Wydawnictwo Uniwersytetu w Białymstoku, 1998.

Dubas-Urwanowicz, Ewa. „Stosunek Korony do unii z Litwą w latach 1562-1574”. Studia Podlaskie 5 (1995): 5-41.

Dunin-Kozicki, Zygmunt. „Nieznane pismo Łukasza Górnickiego o szlachcie wolnej i niewolnej". Miesięcznik Heraldyczny 4, nr 1/2 (1911): 4-6; nr 3/4 (1911): 40-43.

Dzieduszycki, Maurycy. Piotr Skarga i jego wiek. T. 2. Kraków: Wydawnictwo Dzieł Katolickich, 1869.

Dzięgielewski, Jan. Sejmy elekcyjne, elektorzy, elekcje 1573-1674. Pułtusk: Wyższa Szkoła Humanistyczna im. Aleksandra Gieysztora, 2003.

Gierowski, Józef Andrzej. Sejmik Generalny Księstwa Mazowieckiego na tle ustroju sejmikowego Mazowsza. Wrocław: Wrocławskie Towarzystwo Naukowe, 1948.

Gruszecki, Stefan. „Podlaski fragment walki o władzę po śmierci Zygmunta Augusta". Rocznik Białostocki 10 (1971): 35-52.

Gruszecki, Stefan. Walka o władzę w Rzeczypospolitej Polskiej po wygaśnięciu dynastii Jagiellonów (1572-1573). Warszawa: Państwowe Wydawnictwo Naukowe, 1969.

Jabłonowski, Aleksander. Podlasie. Cz. 2. Warszawa: skład główny u Gebethnera i Wolffa, 1909.

Kalinowski, Emil. Kalinowscy herbu Ślepowron w XVII wieku. Warszawa: Neriton, 2013.

Kalinowski, Emil. „Podlasianin Wielkopolaninem? Z nieznanych dziejów przynależności terytorialnej Podlasia po 1569 r.". Przegląd Historyczny 106, nr 3 (2015): 421-440.

Kalinowski, Emil. „Strachy na Lachy - na Podlasiu: szlachta ziemi bielskiej w walce z powstaniem Chmielnickiego (1648-1649)". Przeglad Historyczny 105, nr 1 (2014): 21-58.

Kopczyński, Michał, Jakub Brodacki. „Obywatele czy tłum? Elektorzy władców Rzeczypospolitej z województwa mazowieckiego w latach 1632-1764". Przegląd Historyczny 106, nr 1 (2015): 119-139.

Korolko, Mirosław. „Spory i polemiki wokół konfederacji warszawskiej w latach 1573-1576". Odrodzenie i Reformacja w Polsce 17 (1972): 65-94.

Lasocki, Zygmunt. „Szkice z życia szlachty zawkrzeńskiej w XV i XVI wieku”. Miesięcznik Heraldyczny 11, nr 3 (1932): 50-57.

Lulewicz, Henryk. Gniewów o unię ciąg dalszy. Stosunki polsko-litewskie w latach 15691588. Warszawa: Neriton, 2002. 
Łopatecki, Karol. Organizacja, prawo i dyscyplina w polskim i litewskim pospolitym ruszeniu (do połowy XVII wieku). Białystok: Instytut Badań nad Dziedzictwem Kulturowym Europy, 2013.

Łoziński, Władysław. Prawem i lewem. Obyczaje na Czerwonej Rusi w pierwszej połowie XVII wieku, oprac. Janusz Tazbir. Warszawa: Iskry, 2005.

Maroszek, Józef. Dzieje województwa podlaskiego do 1795 roku. Białystok: Wydawnictwo Uniwersytetu w Białymstoku, 2013.

Maroszek, Józef. Pogranicze Litwy i Korony w planach króla Zygmunta Augusta. Białystok: Wydawnictwo Uniwersytetu w Białymstoku, 2000.

Naworski, Zbigniew. Sejmik generalny Prus Królewskich 1569-1772. Organizacja i funkcjonowanie na tle systemu zgromadzeń stanowych. Torun: Wydawnictwo UMK, 1992.

Opaliński, Edward. „Szlachta małopolska a bezkrólewia”. Kwartalnik Historyczny 105, 3 (1998): 97-104.

Płaza, Stanisław. Próby reform ustrojowych w czasie pierwszego bezkrólewia, 1572-1574. Kraków: Uniwersytet Jagielloński; Państwowe Wydawnictwo Naukowe, 1969.

Płaza, Stanisław. Wielkie bezkrólewia. Kraków: Krajowa Agencja Wydawnicza, 1988.

Podhorodecki, Leszek. Chocim 1621. Warszawa: Bellona, 2008.

Rachuba, Andrzej. „Diety poselskie w Wielkim Księstwie Litewskim XVI-XVII w. na przykładzie sejmiku żmudzkiego". W Z dziejów kultury prawnej: studia ofiarowane Profesorowi Juliuszowi Bardachowi w dziewięćdziesięciolecie urodzin, 599-606, Warszawa: Liber, 2004.

Radaman, Andrej. „Uchwała sejmikowa powiatu nowogródzkiego z 1568 r. a system finansowania posłów sejmowych Wielkiego Księstwa Litewskiego". W Litwa w epoce Wazów, red. Wojciech Kriegseisen, Andrzej Rachuba, 157-174. Warszawa: Neriton; Instytut Historii PAN, 2006.

Rusiniak, Łukasz. „Podlascy elektorowie królów”. Praca magisterska, Instytut Historyczny Uniwersytetu Warszawskiego, 2012.

Siedlecki, Jan. „Kancelaria ziemi bielskiej w Brańsku w XVI-XVIII wieku”. Zeszyty Naukowe Filii UW w Białymstoku. Prace Historyczne 12 (1988): 29-54.

Smoleński, Władysław. „Udział szlachty mazowieckiej w elekcjach królów”. Przegląd Historyczny 1, nr 1 (1905): 52-66.

Starczenko, Natalia. „Zapowiedź zemsty na Wołyniu w 2. połowie XVI - na początku XVII wieku". Barok. Historia, literatura, sztuka 18, nr 1 (2011): 283-312.

Zakrzewski, Andrzej. Sejmiki Wielkiego Księstwa Litewskiego XVI-XVIII w. Ustrój i funkcjonowanie: sejmik trocki. Warszawa: Liber, 2000.

Zieliński, Ryszard. „Województwo płockie w czasie bezkrólewi i na elekcjach”. Notatki Płockie 3, nr 9 (1958): 3-11.

Biog ram: Emil Kalinowski - doktorant w Instytucie Historycznym Uniwersytetu Warszawskiego; obszar zainteresowań: drobna szlachta koronna w epoce przedrozbiorowej, dzieje województwa podlaskiego; e-mail: e.kalinowski@uw.edu.pl. 